\title{
Spektral Açı Haritalama Tekniği İle Aşağı Seyhan Ovası Tarsus - Karataş Arasının Arazi Değişiminin Belirlenmesi
}

\author{
Mamadou Traore ${ }^{1}$, Senem Tekin ${ }^{1, *} \oplus$, Tolga Çan $^{1} \odot$ \\ ${ }^{1}$ Çukurova Üniversitesi, Mühendislik Fakültesi, Jeoloji Mühendisliği Bölümü, 01330, Sarıçam, Adana.
}

\section{Özet}

Yaşam alanlarını oluşturan kara parçalarının bilinçsiz ve kontrolsüz kullanımı nedeni ile ortaya çıkan olumsuzlukların, doğada neden olduğu tahribatı engellemeye yönelik doğayı ve doğal kaynakları koruma düşüncesi arazi kullanım planlamalarının önemini artırmaktadır. Bu çalışmada, Çukurova'nın güney kesiminde ekolojik olarak öneme sahip olan doğal koruma alanlarından biri olan Akyatan yaban hayatı geliştirme sahasını da içeren ve Ramsar koruma alanlarının da yer aldığı, bir klsmı ile Seyhan ovası içerisinde bulunan Tarsus (Mersin) ile Karataş (Adana) arasındaki bölgede, 1985, 2000 ve 2019 yılları arasındaki arazi kullanımında meydana gelen değişimler incelenmiştir. Analizlerde 30 m mekânsal çözünürlüğe sahip Landsat-5TM 1985, Landsat-5TM 2000 ve Landsat-8 OLI 2019 uydu görüntüleri kullanılmıştır. Uydu görüntüleriyle öncelikli olarak geometrik, radyometrik kalibrasyon ve atmosferik düzenlemelerden oluşan ön işleme çalışmaları gerçekleştirilmiştir. Arazi kullanım değiş̧im tespitinde Spektral Açı haritalama yöntemi kullanılmıştır. Elde edilen sonuçlara göre 1985-2019 yılları arasında yerleşim, ekili olmayan tarım, orman ve yarı doğal ve lagün/göller alanlarında \%192,\%37,\%7 ve \%8'lik büyüme gelişirken, çılak ve ekili tarım alanlarda ise \%43 ve \%21'lik oranlarda azalmalar meydana gelmiştir. Aynı zamanda ülkemizde bulunan aktif fay hatlarından biri olan Karataş fayı civarında 500, 1000 ve 2000 m'lik tampon bölgeler içerisinde yerleșim birimlerinde meydana gelen değișimler değerlendirilmiștir. Karataș fayı civarında ise yerleşimin 1985 ile 2019 yılları arasında yapılaşmaların \%192 oranında arttı̆̆ belirlenmiştir. Yapılan kontrollü sınıflama çalışmalarının doğruluğu kappa istatistiği ile değerlendirilmiş olup 1985, 2000 ve 2019 yılları için sirasıyla 0.80, 0.84, 0.87 olarak hesaplanmiştır.

\section{$\underline{\text { Anahtar Sözcükler }}$}

Arazi Kullanım Planlamaları, Uzaktan Algılama, Landsat, Spektral Açı Haritalama

\section{Land Use Change Detection Between Tarsus - Karataş in Lower Seyhan Plain with Spectral Angle Mapper Technique}

\begin{abstract}
The idea of protecting the nature and natural resources in order to prevent the damages caused by unconscious and uncontrolled use of the land pieces constituting the habitats increases the importance of land use planning. The region between Tarsus (Mersin) and Karataş (Adana) located in the Ramsar protected areas, including the Akyatan wildlife development area, which is one of the ecologically important natural conservation areas in the southern part of Çukurova is selected to be examined the land use changes between 1985, 2000 and 2019 in this study. Landsat-5TM 1985, Landsat-5TM 2000 and Landsat-8 OLI 2019 satellite images with a spatial resolution of $30 \mathrm{~m}$ were used in the analyzes. Pretreatment studies, which consist primarily of geometric, radiometric calibration and atmospheric arrangements, have been performed with satellite images. Spectral Angle mapping method was used for land use change detection. According to the results obtained, growth of 192\%, 37\%, 7\% and 8\% growth in settlement, non-cultivated agriculture, forest and semi-natural and lagoon / lakes areas between 1985-2019, and 43\% and 21\% in bare and cultivated agricultural areas Decreases in rates of 21 have occurred. It was determined that the settlements around the Karatas fault increased by 192\% between 1985 and 2019. The accuracy of the controlled classification studies was evaluated with kappa statistics and calculated as 0,80, 0,84, 0,87 for 1985, 2000 and 2019, respectively.
\end{abstract}

$\underline{\text { Keywords }}$

Land Use Planning, Remote Sensing, Landsat, Spectral Angle Mapping

\section{Giriş}

Arazi değişimi küresel nüfus artışı, iklim değişimleri, yaşam standartları ve yaşam koşullarına göre geçmişten günümüze sürekli değişim içerisindedir. Gelişmekte olan ülkelerde düzensiz yapılaşma, plansız büyümeler neticesinde özellikle yerleşime uygun olmayan alanlara doğru birçok bölgede yerleşim yerleri artmaktadır.

\footnotetext{
* Sorumlu Yazar: Tel: +90 (506) 5510065 Faks: +90 (322) 3386715

E-posta: matraba77@gmail.com (Traore M), senemtekin01@gmail.com (Tekin S), 
Avrupa Çevre Ajansı tarafından Türkiye'nin de içinde bulunduğu 39 ülke için 1985 yılında başlatılan CORINE (Coordination of Information on the Environment - Çevresel Bilginin Koordinasyonu) Projesi kapsamında belirlenen arazi örtüsü sınıfları doğrultusunda 3 farklı seviyede, uydu görüntüleri kullanılarak 1/100.000 ölçekte 1990, 2000, 2006, 2012, 2018 yılları arazi örtüsü haritaları oluşturulmuştur. Arazi kullanımında meydana gelen değişimler çok farklı açılardan önem arz etmektedir. Bu değişimler özellikle doğal ekosistemin, topoğrafik yapının, ziraat alanlarının değişimi ile yaşam standartlarını da doğrudan etkilemektedir. Sürdürülebilir kalkınma planlama analizlerine yönelik öngörülerde, farklı zamanlara ait görüntüler ile değişim analizleri önemli hususlardan birini oluşturmaktadır. Uzaktan algılama teknikleriyle arazi değişim tespitleri, kullanılacak yöntemlerinin doğru seçilmesi ve sonuç çıktıların doğruluğu istatistiksel olarak değerlendirilmesiyle elde edilmektedir. Bu değerlendirmeler, sadece arazi kullanımında meydana gelen değişimlerin değerlendirilmesini içeriyor gibi görünse de, aynı zamanda sürdürülebilir kalkınma politikalarının bölgesel ölçekte ne şekilde değiştiğini ve gelecekte de nasıl şekilleneceğine yönelik varsayımları ortaya çıkarmaktadır (Paul ve Rashid 2017).

Uzaktan algılama teknikleri ile arazi kullanımında meydana gelen değişimlerin tespitinde birçok yöntem kullanılmaktadır (Helmer vd. 2000; Dennison vd. 2004; Irish vd. 2006; Elatawneh vd. 2010; Anggraeni ve Lin 2011; Huang vd. 2012; Forzieri vd. 2013; Borges ve Sano 2014; Agapiou vd. 2014; Elmahdy ve Mohamed 2016; Aswatha vd. 2017; Adep vd. 2017; Karakus vd. 2017; Awad 2018). Arazi kullanımında meydana gelen değişimler, obje tabanlı olup nesneler arasındaki benzerlik derecelerine göre sınıflandırılmaktadır. Genel olarak değişim analizi farklı zamanlara ait uydu görüntülerinde, meydana gelen değişimlerin sayısal olarak belirlenmesini amaçlayan uygulamalar bütünüdür. Bu kapsamda genel olarak, arazi kullanımında meydana gelen değişiklerin tespitinde çok zamanlı uydu görüntülerine ve bu görüntülerin ön işleme aşamaları olan, geometrik ve atmosferik düzeltmelerin doğru değerlendirilmesine bağlı olup bu veriler doğrultusunda yapılacak sınıflama çalışmalarının doğruluğunun da mutlaka incelenmesini gerektirmektedir (Stow 1999; Verbyla ve Boles 2000; Carvalho vd. 2001; Nigussie ve Altunkaynak 2019; Olayiwola ve Fakayode 2019; Padmanaban vd. 2019; Putro ve Prasetiyowati 2019; Rahman vd. 2019; Thanikachalam ve Nimalan 2019; Tornaghi ve Dehaene 2019; Yoon vd. 2019). Bu çalışmada, Çukurova'nın güney kesiminde ekolojik olarak öneme sahip olan doğal koruma alanlarından biri olan Akyatan yaban hayatı geliştirme sahası, Tuzla lagünleri gibi yaban hayatı geliştirme sahaları ve koruma alanları, Magarsus Antik Kenti Arkeolojik Sit Alanı gibi koruma alanlarının olduğu 2036 km²'lik bölgede Landsat uydu görüntüleri ile 34 yıllık süre içerisinde arazi sınıflarında meydana gelen değişimlerin ortaya çıkarılması amaçlanmış ve spektral açı haritalama (SAH) yöntemi kullanılarak arazi değişim tespiti yapılmıştır.

\section{2. Çalışma Alanı ve Materyal}

Çalışma alanı Çukurova ovasının Akdeniz ile kesiştiği bölgeyi içermekte olup (Şekil 1) Seyhan deltasının güney kesimlerini de kapsamaktadır. Çukurova Ovası, Batıdan ve kuzeyden Orta Toroslar ile sınırlı olup 3500 m yüksekliklere ulaşmaktadır. Doğuda Ceyhan nehri batıda Seyhan nehri ve Tarsus (Berdan) çayının alüvyonlarından oluşan Güney ve güneybatıdan Akdeniz'e dökülen Çukurova alüvyonları, Adana ovasının yaklaşık üçte ikisini oluşturmaktadır. Alüvyon ovası, yazları sıcak ve kurak Akdeniz iklimine sahiptir. Jeolojik olarak oluşumunu Kuvaterner'de tamamlayan Çukurova özellikle sulu tarım yapılan topraklarıyla önem arz eden ovalardan biridir. Çalışma alanı $2036 \mathrm{~km}^{2}$ olup bu alanın 1296 $\mathrm{km}^{2}$ 'si Adana, $370 \mathrm{~km}^{2}$ 'si ise Mersin il sınırlarını içerisinde yer almaktadır (Şekil 1).

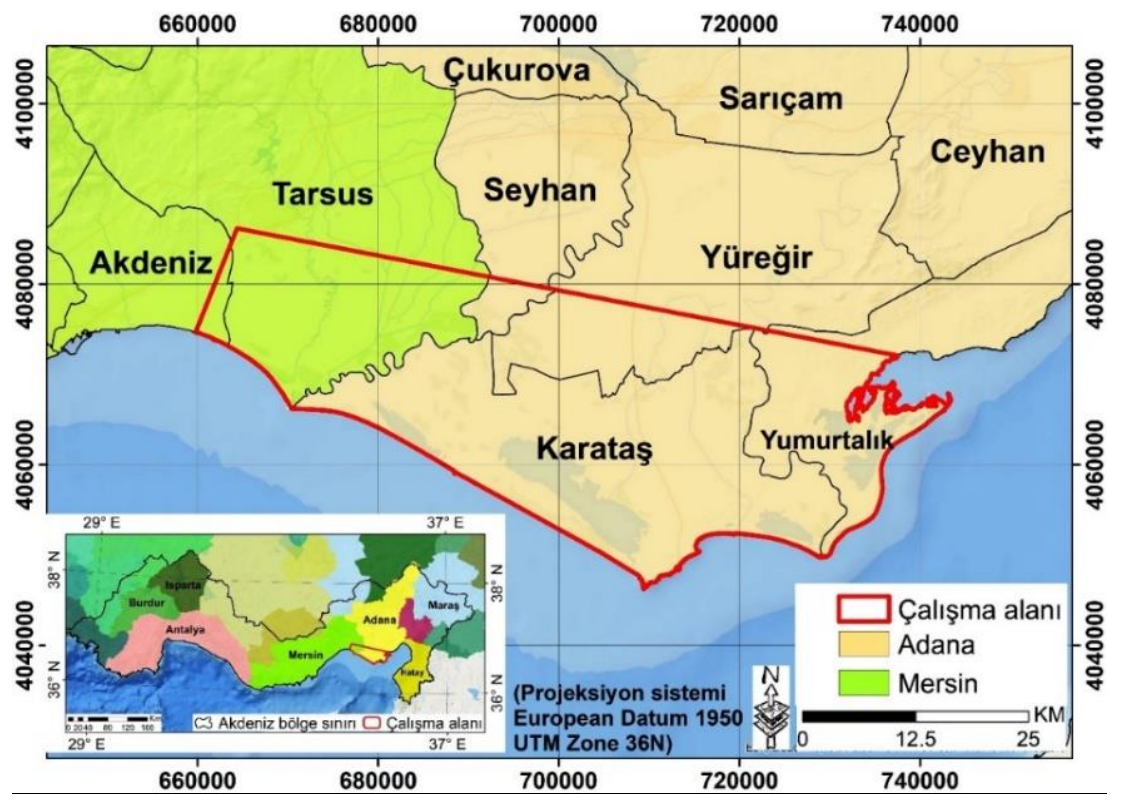

Şekil 1: Çalışma alanına ait yerbulduru haritası 
Çalışma alanı Adana basenini bir yükselim ile İskenderun baseninden ayıran Misis yapısal yükseliminin bir bölümünü içermektedir. Adana'dan 50 km kadar güneyinde olan inceleme alanı yaklaşık olarak Karataş (Adana) ile Tarsus (Mersin) arasını kapsamaktadır. Türkiye aktif diri fay haritalarından biri olan Karataş fayı çalışma alanı içerisinden geçmektedir. Tektonik açıdan aktif ve önemli konumda bulunan bölgede, en yaşlı olarak Alt-Orta Miyosen yaşlı Karataş Formasyonu; türbiditik karakterli kumtaşı, kumlu kireçtaşı, marn, kireçtaşı ve konglomera ardalanması ile yer yer değişik boyutlarda olistolitlere ait blokları içeren birimden oluşmaktadır (Ulu 2009a). Miyosen yaşlı birim üzerine Kuvaterner çökelleri gelmekte olup özellikle Karataş fayının Akdeniz'e uzandığı kesimde Kaliş birimi gelmektedir (Ulu 2009b). Çukurova deltasını oluşturan kumtaşı, çakıltaşı litolojisinden oluşan ve geniş alanlarda yüzeyleyen delta çökel birimleri yer almaktadır. En güncel birim olarak da düz alanlarda kumul ve plaj çökelleri bulunmaktadır (Şekil 2).

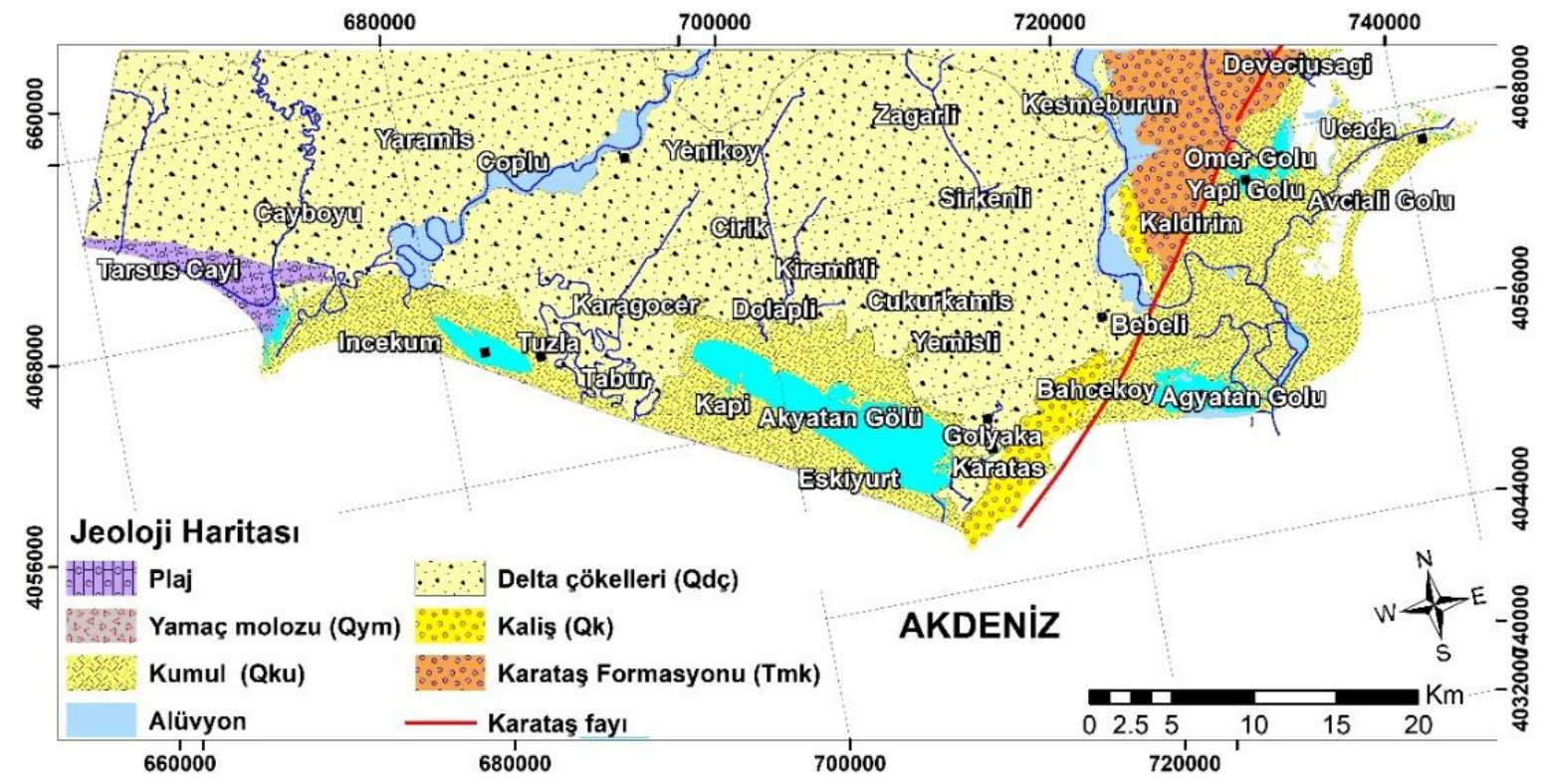

Şekil 2: Çalışma alanına ait aktif fay ve jeoloji haritası (Ulu 2009a,b)

CORINE arazi örtü haritası 3 farklı seviyede 1985 yılından itibaren hazırlanmaya başlanmıştır (URL-1 2019). Proje kapsamında 1990, 2006, 2012 ve 2018 yıllarında aynı standartlar kullanılarak birçok ülkede meydana gelen arazi değişimlerinin tespit edilmesi amaçlanmıştır. Çalışma alanına ait 1990 - 2018 yılları arasında meydana gelen arazi değişimlerine göre yapay kütleler ve su kütlelerinde artış olurken, tarımsal alanlar ve sulak alanlarda azalma meydana geldiği görülmektedir (Şekil 3, Şekil 4). Orman ve yarı doğal alanlarda ise neredeyse değişim bulunmamaktadır.

Çalışma alanında, Akdeniz ikliminin hakim olması sebebiyle özellikle tarımsal faaliyet açısından mevsimsel olarak sonbahar - kış ayları arasında değişim hemen hemen yoktur. Aynı zamanda coğrafi yapı açısından da farklılık gözlenmemektedir. Bu sebepten dolayı Eylül - Kasım ayları arasındaki görüntüler tercih edilmiştir. USGS'de bulunan görüntüler tek tek incelenmiş olup, radyometrik, mekânsal bozukluk olmaması, bulutluluk oranı gibi temel tüm kriterlere göre belirlenmiştir. Sonuç olarak Çalışma kapsamında, arazi kullanımında meydana gelen değişimler $175 / 35$ yörüngesine ait, 30 m mekansal çözünürlükte olan, 03.11.1985 Landsat-5 TM (Şekil 5a), 09.09.2000 Landsat-5 TM (Şekil 5b) ve 17.11.2019 Landsat-8 OLI (Şekil 5c) görüntüleri materyal olarak kullanılmıştır.

Yapılan sınıflama kümeleri CORINE sınıflarına benzer şekilde isimlendirilmiş ve çalışma alanını oluşturan bölgeleri yansıtacak arazi sınıfları kullanılmıştır. Bu kapsamda kullanılan uydu görüntüleri, yerleşim, çıplak alan, bitki örtüsü, lagün/su kütleleri ile tarım arazileri ekili ve ekili olmayan alanlar olarak belirlenmiştir. 


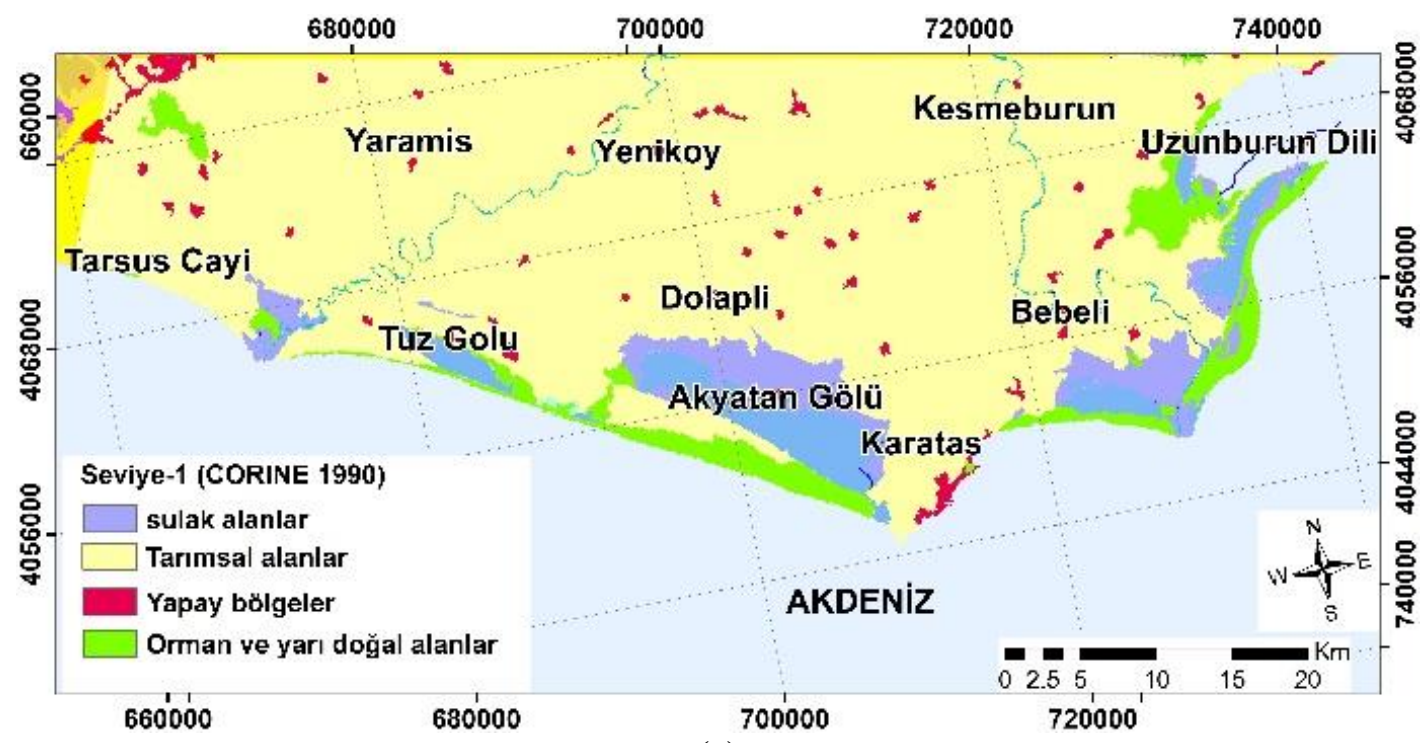

(a)

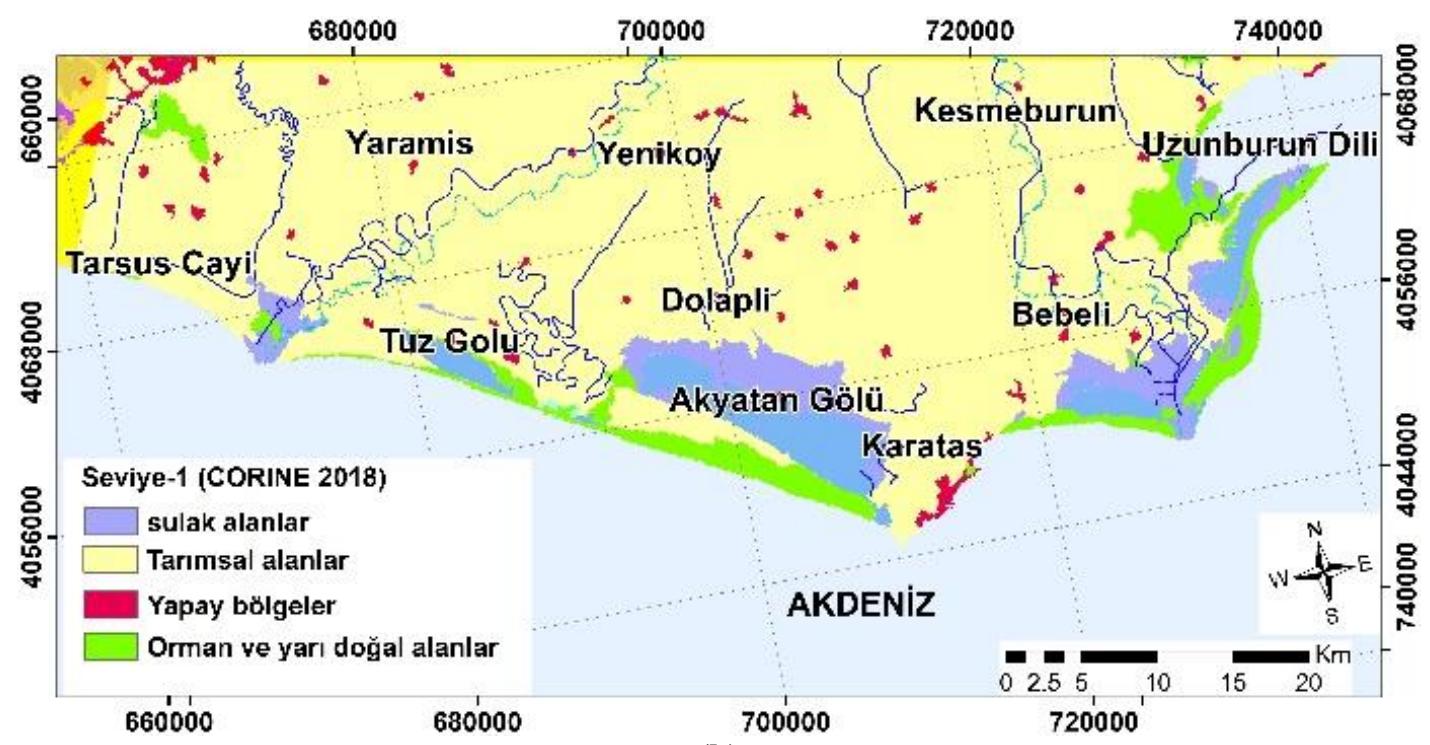

(b)

Şekil 3: CORINE (a)1990, (b) 2018 arazi örtü haritası (URL-2 2019)

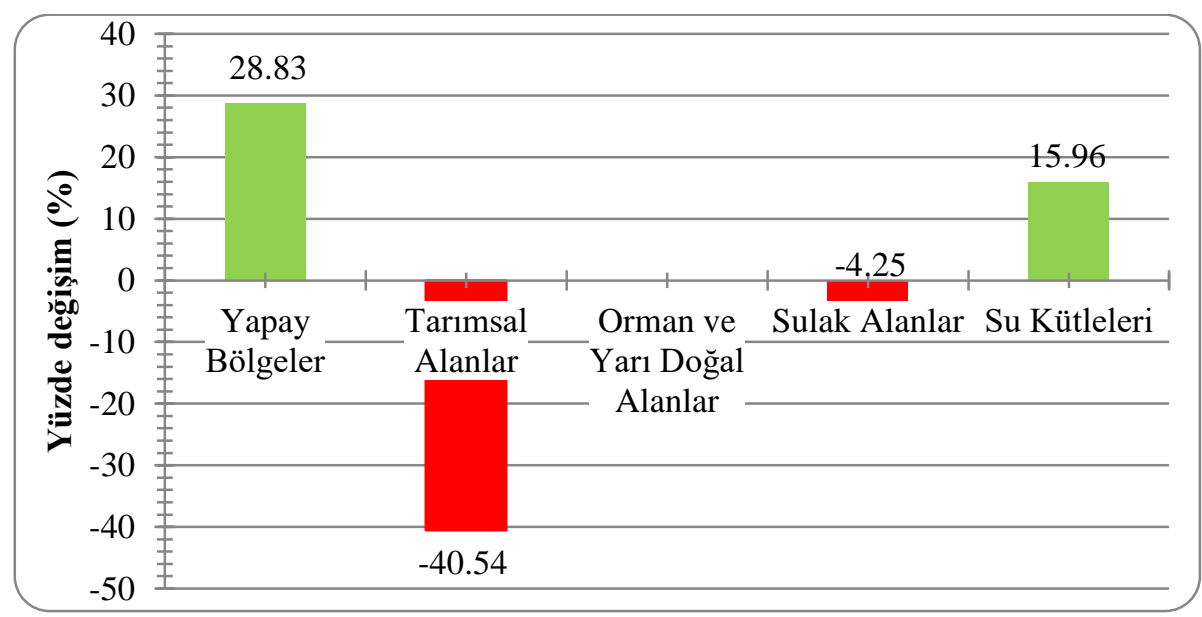

Şekil 4: 1990-2018 yılları arasında CORINE seviye 1 de meydana gelen değişimler (URL-2 2019) 

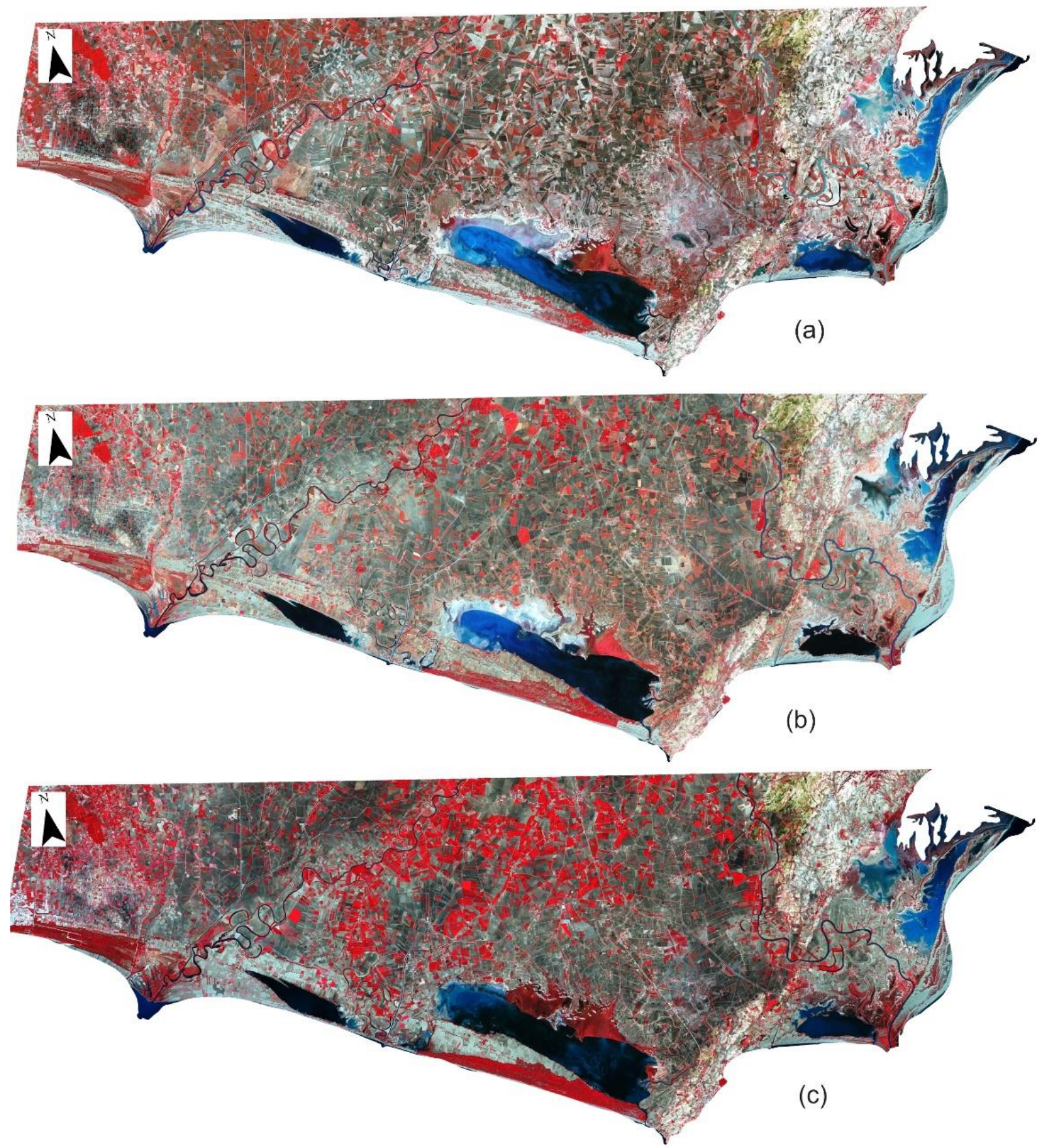

Şekil 5: Çalışmada kullanılan a) 1985, b) 2000 ve c) 2019 Landsat uydu görüntüleri

Son zamanlarda iklim değişimi çalışmalarına göre; geçmişten günümüze bakıldığında mevsimsel değişimler, sıcaklık artışları, yağış rejiminde meydana gelen değişimler hayatı her anlamda olumsuz yönde etkilemektedir. İklim değişikliğinin sonuçlarına hazırlıklı olunması ve olumsuz etkilerinin en aza indirilmesi için iklimde gözlenen değişikliklerin ve eğilimlerin gelecekte nasıl olacağının tahmin edilmesi ve bu değişikliklerin doğal ve insan sistemlerine etkilerinin belirlenmesi ve önlemler alınması için planlamalar yapılmasını gerektirmektedir. Özellikle yaşamın tarımsal faaliyetler gibi alanlarda gerçekleştirilen bölgelerin iklim değişikliğinden en çok etkilenecek alanlardan biri olduğu bilinmektedir (Gündoğan vd. 2017).

CORINE verilerine göre çalışma alanının \% 60’ını tarım bölgeleri oluşturmaktadır. Bu kapsamda, Yaklaşık bir kilometrelik mekansal çözünürlüğe sahip bir dizi küresel iklim katmanları için Worldclim (URL-3 2020) tarafindan hazırlanan iklim verileri çalışma alanı için incelenmiştir. 1960-1990 yılları meteoroloji istasyonlarından alınan veriler 1şığında geleceğe yönelik kestirim modelleri hazırlanmıştır. Bu verilere göre, 1960-1990 yılları arasında çalışma alanında yıllık ortalama sıcaklık değerlerinin $18.5^{\circ}$ ile $19.2^{\circ}$ (Şekil 6a) olduğu 2070 yılında ise bu değerlerde yaklaşık $5^{\circ}$ artış (Şekil 6b) gerçekleşeceği ön görülmektedir. 
Worldclim iklim senaryolarından ortalama yıllık yağış verilerine bakıldığında, günümüz verilerine göre çalışma alanının özellikle güneydoğu kesimlerinde $601 \mathrm{~mm}$ (Şekil 7a) yılık yağış değerlerine ulaştı̆̆ı görülmektedir. 2070 yılında ise bu değerlerde yaklaşık olarak 140 mm'lik azalış olacağı tahmin edilmektedir (Şekil 7b).

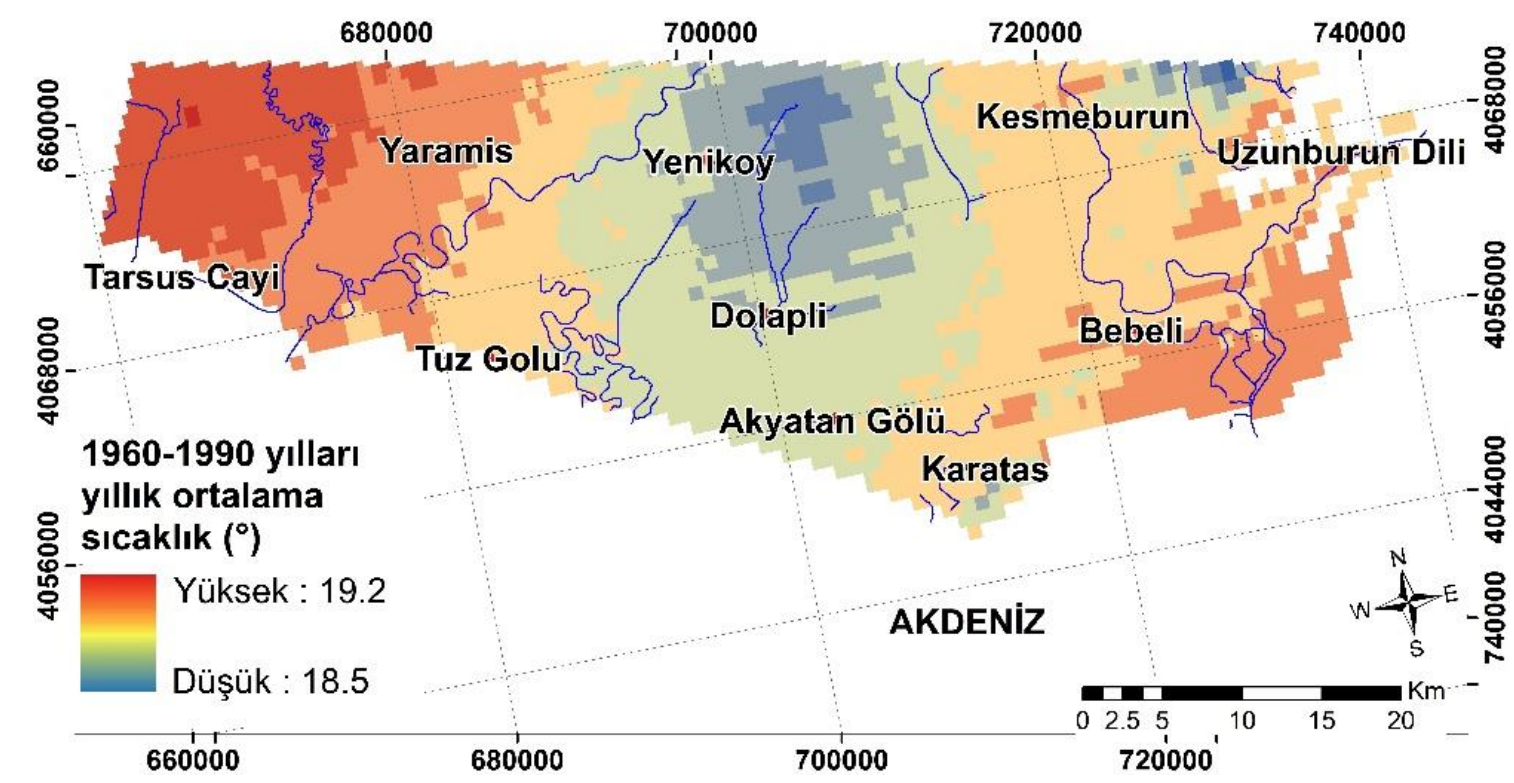

(a)

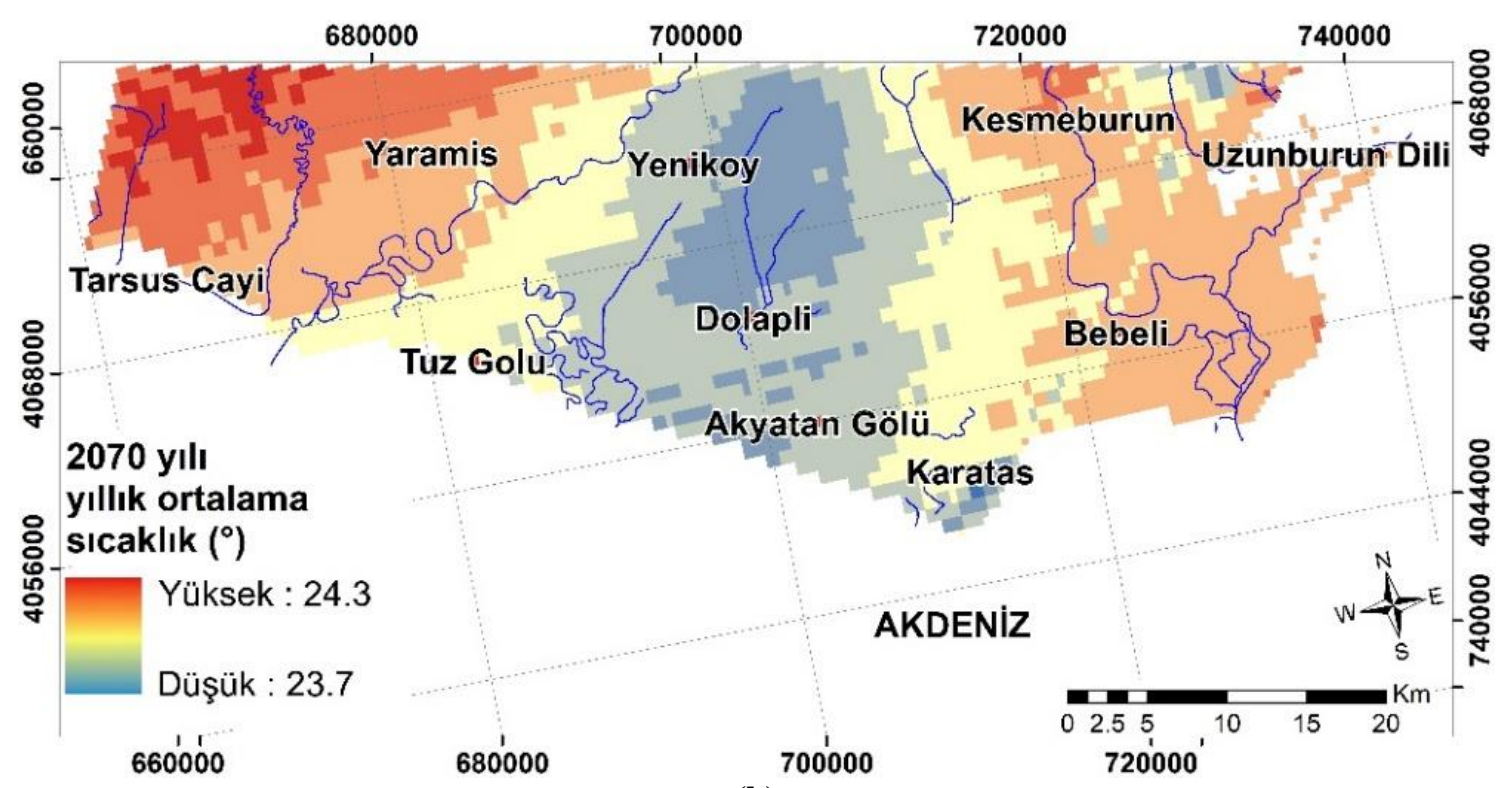

(b)

Şekil 6: a) 1960-1990 yılları, b) 2070 yılı ortalama sıcaklık verileri (URL-3 2020) 


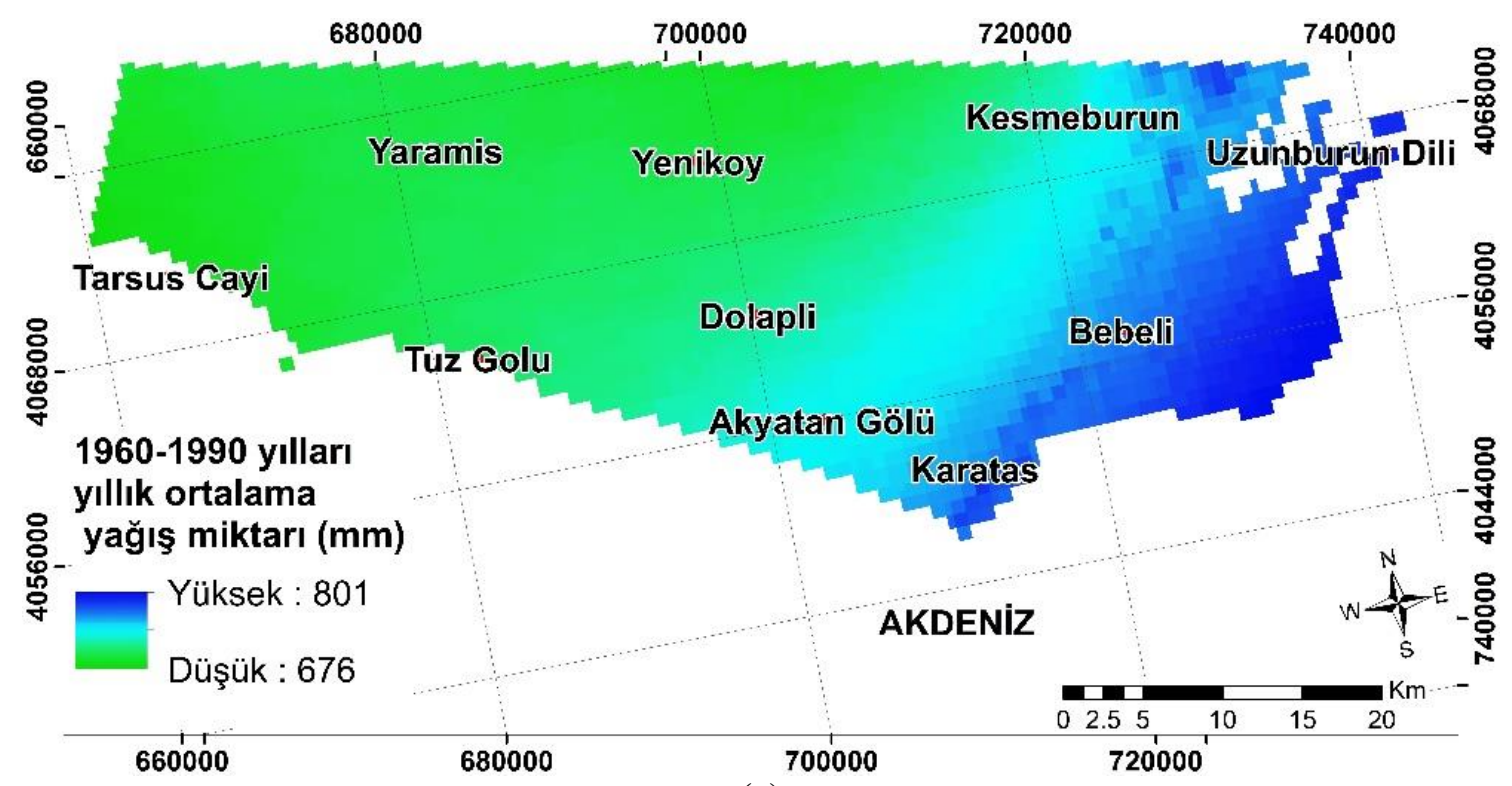

(a)

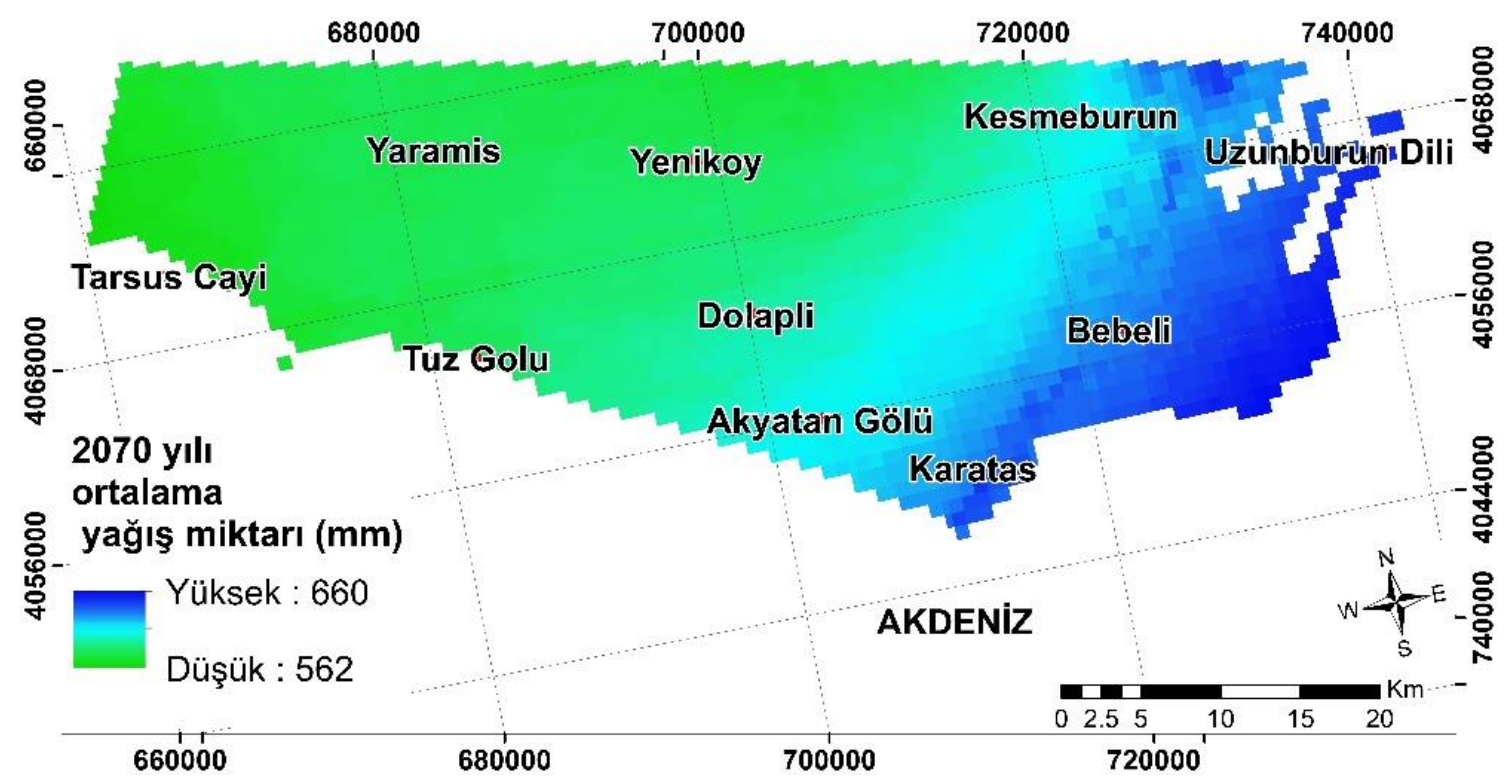

(b)

Şekil 7: a) 1960-1990 yılları, b) 2070 yıına ait yılık ortalama yağış değerleri (URL-3 2020)

Türkiye toprak haritasında (Karabulut vd. 2011) yer alan sınıflamalardan biri olan arazi kullanım şekline göre olan sınıflama değerlendirildiğinde çalışma alanının \%32'sinin kuru tarım (nadassız) olarak isimlendirilen sınıfta yer aldığı görülmektedir. Özellikle Tarsus çayı kuzey kesimlerinde ise \%26 oranında sulu tarıma elverişli tarım arazilerinin olduğu görülmektedir. Çalışma alanının güney kesimlerinde bulunan Lagün sınırları civarında ise terkedilmiş (hali) arazi sınıflarının olduğu görülmektedir. Genel olarak değerlendirildiğinde ise çalışma alanının yaklaşık \%35'lik kısmının tarıma elverişli topraklara sahip olduğu görülmektedir (Şekil 8). 


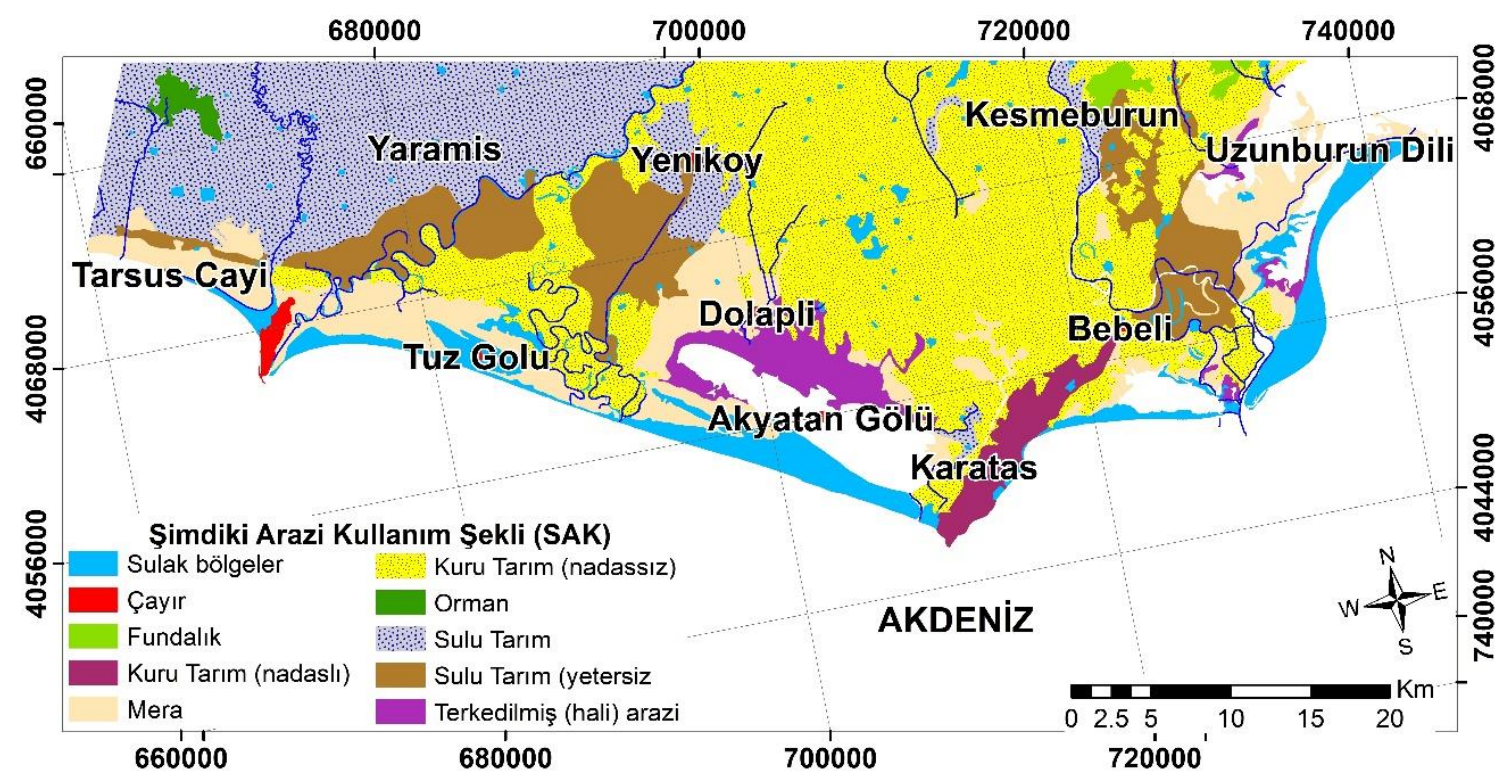

Şekil 8: Toprak haritası (Karabulut vd. 2011)

\section{Metot}

Arazi kullanım değişim tespitleri, farklı en az üç tarihli görüntü kullanılarak meydana gelen değişimlerin belirlenmesidir. Arazi sınıflarında meydana gelen değişimlerin tespiti çalışmaları, başlıca, görüntü önişleme, görüntü işleme ve elde edilen arazi sınıflarına ait doğruluk analizlerinin gerçekleştirilmesiyle elde edilmektedir (Şekil 9). Görüntü önişleme aşaması geometrik, radyometrik ve atmosferik düzeltme olmak üzere 3 aşamada gerçekleştirilmektedir. Geometrik düzeltme aşamasında analizlerde kullanılan 3 görüntü arasındaki geometrik bozukluklar belirli kontrol noktaları kullanılarak birbiri ile uyumlu hale getirilmektedir. Ham haldeki uydu görüntülerinde geometrik bozulma etkileri var ise bunların giderilmesini içermektedir.

Bu çalışmada Transverse Mercator projeksiyonu ve ED50 datumu kullanılmıştır. 31.11.1985 ve 09.09.2000 tarihli görüntüler ile 17.11.2019 tarihli görüntüler belirlenen kontrol noktalarına göre incelenmiştir. Lunetta ve Elvidge (1998)'e göre Kök Ortalama Kare Hata (RMSE) değerinin 0.5'den küçük olması gerektiği söylenmektedir. 1985, 2000 ve 2019 yıllarına ait görüntülere ait Kök Ortalama Kare Hata (RMSE) değeri 0.3'den küçük hesaplanmış olup bu çalışmada elde edilen RMSE değeri kullanılabilir ölçüdedir.

Radyometrik düzeltme aşamasında ise; görüntülerdeki düzensiz ve yanlış algılamalara neden olan atmosferik etkilerin giderilmesi ve algılayıcılar tarafından algılanan radyasyondan objeleri tam olarak temsil etmeyen yansımaların düzeltilmesi amacıyla radyometrik kalibrasyon düzeltmeleri gerçekleştirilmiştir. Su buharı ve aerosoller gibi atmosferik etkileri ortadan kaldırmak için, çalışmada kullanılan Landsat uydu görüntülerinde, atmosferik düzeltme flat field (topoğrafik), empirical line ve FLAASH (Fast Line-of-sight Atmospheric Analysis of Hypercubes) gibi yöntemleriyle gerçekleştirilmiş fakat çalışılan bölgeye ait en iyi parklaklığın elde edildiği FLAASH yöntemi ile zenginleştirilmiş görüntüler kullanılmıştır. Kontrollü sınıflandırma yöntemlerinden spektral açı haritalama (SAH) yöntemi tercih edilmiştir. Uydu verileri ile kullanılan birçok haritalama ve sınıflandırma analizlerinden en popülerinden biri olan SAH yöntemi, nesneler arasındaki benzerlik derecesinin kullanıldı̆̆ bir sınıflandırma yöntemidir (Kruse vd. 1993; Rowan vd. 2005; Massironi vd. 2008; Gürsoy 2016; Fan vd. 2018; Ahmad vd. 2019; Gopinath vd. 2020; Gannouni ve Rebai 2020). SAH, her nesnenin yansıtma değerleri, yönü ile hedef sınıflama grupları arasındaki özellikleri belirlemektedir. Her bir nesne, vektörel olarak ifade edilmekte ve belirli bir uzunluğu bulunmaktadır. SAH yönteminde, referans olarak kullanılan spektral yansıtım verilerine göre oluşturulan referans vektörü ile uydu görüntüsü piksel değerlerinden meydana gelen, sınıfı bilinmeyen piksel değerleri ile oluşturulan vektör arasındaki açı hesaplanmaktadır (Şekil 9). Hesaplanan açı değeri, daha önceden referans spektral sınıfı için belirlenen benzerlik değerinden küçük veya eşitse, sınıfı bilinmeyen piksel, ilgili referans spektral sınıfına atanmaktadır (Luc vd. 2005). Bu çalışmada her iki referans veri içinde benzerlik eşik değeri 0.025 radyan olarak tespit edilmiştir. Bantların geri yansımasındaki değişkenlikler, vektörün uzunluğunu etkilemektedir. Bu nedenle farklı spektral değerler arasındaki karakteristik değişkenlikler kendilerine ait vektörler arasındaki açının da değişmesine neden olmaktadır. SAH'da, verinin bilinen yansıtım değerlerinin fiziksel olarak, iki spektrum arasındaki benzerlikleri spektral vektörleri arasındaki açıları kullanarak hesaplayan bir algoritma ile çalışmaktadır (Uysal vd. 2017). Uydu görüntülerinden elde edilen sınıflandırma sonuçlarının doğruluk analizleri, Sınıflandırılmış görüntüde, verilerin içerdikleri hata oranlarının yani, sınıflandırılmış görüntünün gerçekliğe uygunluk durumunun belirlenmesi için, sınıflandırılmış görüntüden seçilen test alanlarının, yer gerçeği verileri ile karşılaştırılmasıyla gerçekleştirilmiştir. 


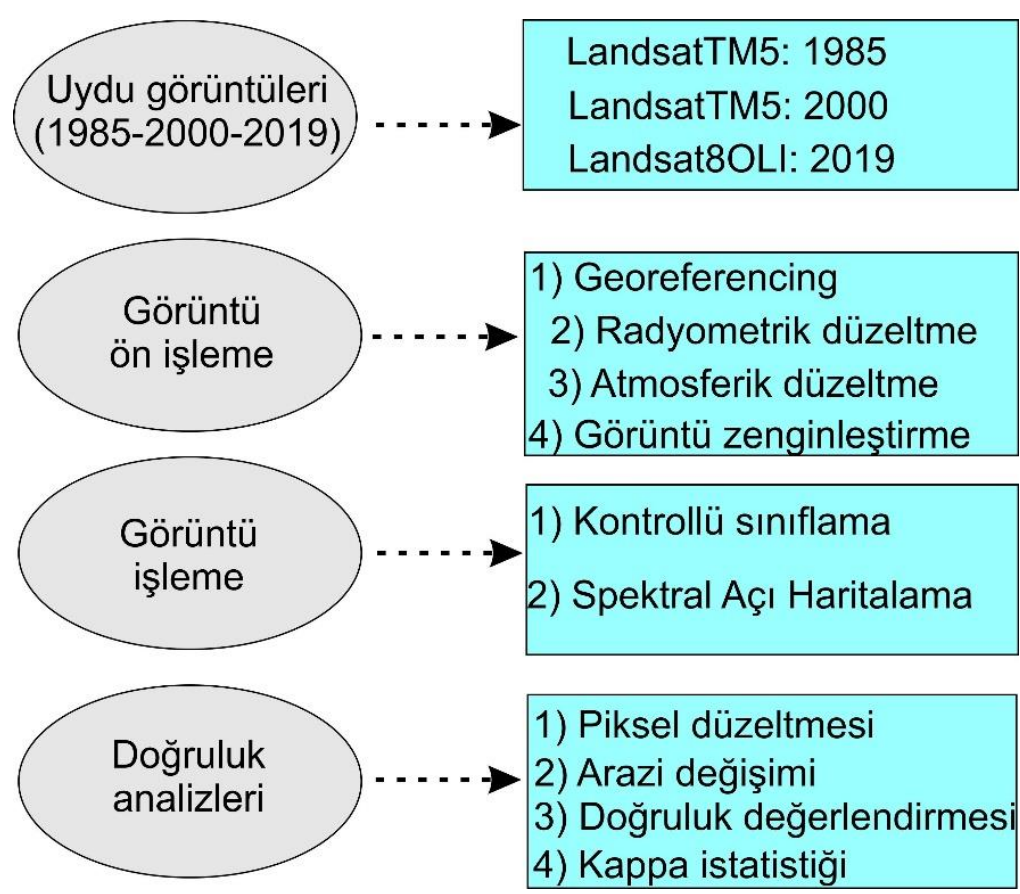

Şekil 9: Çalışma yönteminde izlenen aşamalar

\section{Bulgular}

Bu çalışmada, Çukurova'nın güney kesiminde ekolojik olarak öneme sahip olan Akyatan lagünü, yaban hayatı geliştirme sahası, Tuzla lagünleri gibi yaban hayatı geliştirme sahaları ve koruma alanları, Magarsus Antik Kenti Arkeolojik Sit Alanı gibi koruma alanlarının olduğu $2036 \mathrm{~km}^{2}$ 'lik bölgede uzaktan algılama ile Landsat uydu görüntüleri kullanılarak 34 yıllık süre içerisinde arazi sınıflarında meydana gelen değişimler tespit edilmiştir. 3 farklı tarihli uydu görüntüleri yerleşim alanları, ekili olmayan tarım alanlar, ekili tarım alanlar, orman ve yarı doğal alanlar, çıplak alanlar ve lagün/su kütleleri olarak sınıflandırılmıştır (Şekil 10). Buna göre çalışma alanında en yüksek sınıflar 1985, 2000 ve 2019 yılında sırasıyla \% 54.1, \%43 ve \% 37.4 ile ekili olmayan tarım alanlardan oluştuğu belirlenmiştir (Tablo 1).

Çalışma alanına ait 34 yıllık süreçteki arazi sınıflarındaki değişim miktarı eşitlik 1'e göre hesaplatılmış olup \% değişim miktarları ise eşitlik 2'ye göre değerlendirilmiştir (İslam vd. 2017; Wiafe ve Assamoah 2018). Yapılan değerlendirmelere göre özellikle yerleşim birimlerinde artış olduğu görülmektedir. Her bir zaman aralığında meydana gelen yüzde arazi değişimleri Şekil 10a,b ve c'de görülmektedir. 1985 ve 2000 arazi değişim sınıflarından, ekili tarım ve lagün/su kütle alanlarında azalma meydana gelirken, yerleşim, ekili olmayan tarım, orman ve yarı doğal ve çıplak alanlarında artış meydana geldiği belirlenmiş̧tir. 2000 ve 2019 için arazi değişim sınıflarından, çıplak ve orman ve yarı doğal alanlarda azalma meydana gelirken, yerleşim, ekili olmayan tarım, ekili tarım ve lagün/su kütleleri alanlarında artış meydana geldiği belirlenmiştir. 2000 ve 2019 için arazi değişim sınıflarından, çıplak ve ekili tarım alanlarda azalma meydana gelirken, yerleşim, ekili olmayan tarım, orman ve yarı doğal ve lagün/su kütleleri alanlarında artış meydana geldiği belirlenmiştir (Tablo 2).

Alan değişimi $=\dot{I} l k y l l-$ Son yıl

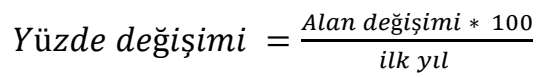



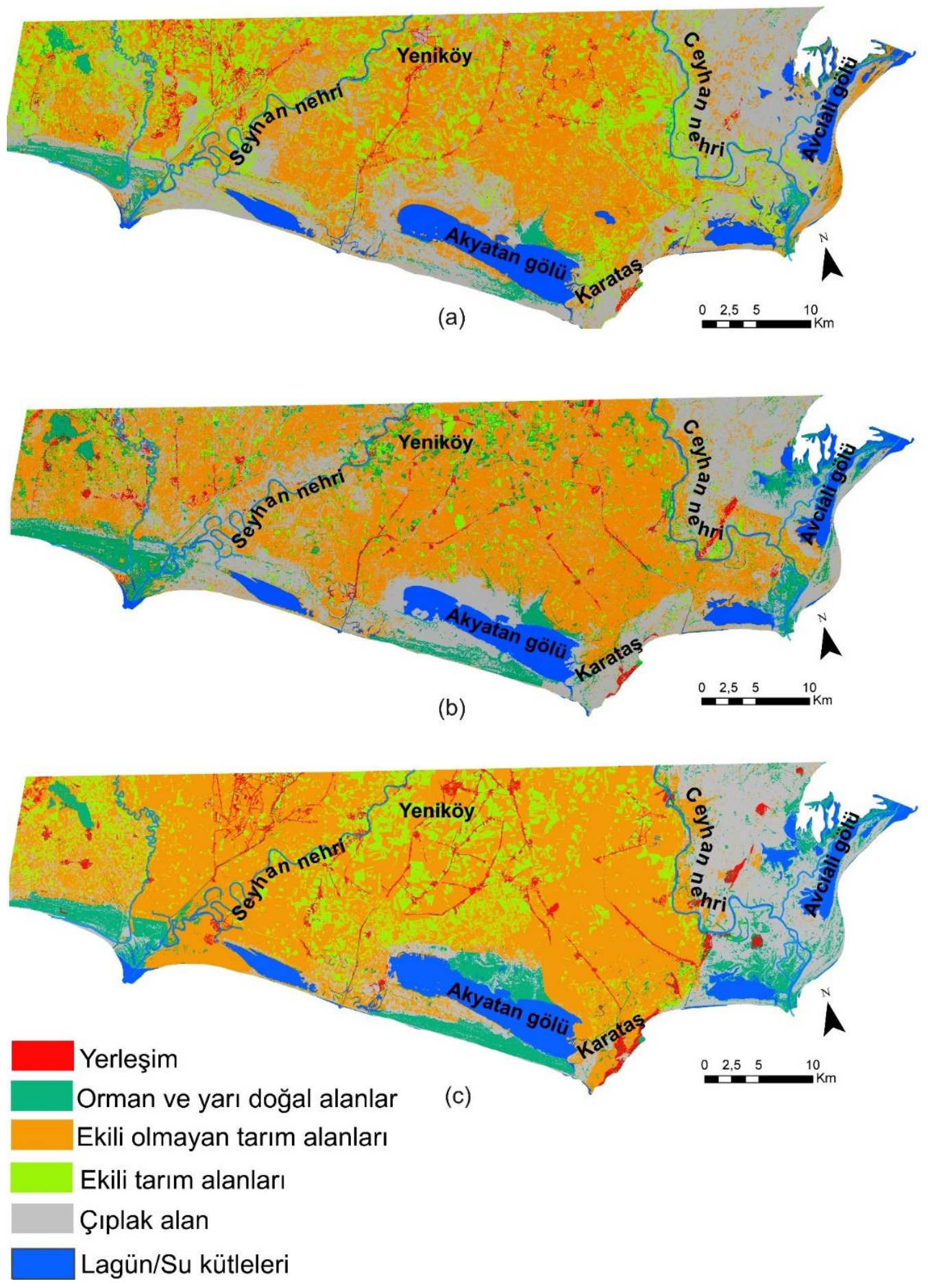

Şekil 10: a) 1985, b) 2000 ve c) 2019 yılları için arazi kullanımı haritası

Tablo 1: 1985, 2000 ve 2019 yıllarındaki arazi kullanımının arazi örtüsü sınıflarına ait alan ve yüzde değerleri

\begin{tabular}{ccc|cc|cc}
\hline & \multicolumn{2}{c}{$\mathbf{1 9 8 5}$} & \multicolumn{2}{c}{$\mathbf{2 0 0 0}$} & \multicolumn{2}{c}{$\mathbf{2 0 1 9}$} \\
\hline Arazi Sınıfları & \multicolumn{2}{c}{ Alan } & \multicolumn{2}{c}{ Alan } & \multicolumn{2}{c}{ Alan } \\
& $\mathbf{k m}^{\mathbf{2}}$ & $\mathbf{\%}$ & $\mathbf{K m}^{\mathbf{2}}$ & $\mathbf{\%}$ & $\mathbf{K m}^{\mathbf{2}}$ & $\mathbf{\%}$ \\
\hline Yerleşim alanlar & 15,3 & 0,9 & 20,8 & 1,3 & 44,7 & 2,7 \\
Ekili olmayan tarım alanlar & 613,8 & 37,4 & 706,1 & 43,0 & 843,3 & 51,4 \\
Ekili tarım alanlar & 273,6 & 16,7 & 90,2 & 5,5 & 215,8 & 13,1 \\
Orman ve yarı doğal alanlar & 119,4 & 7,3 & 157,5 & 9,6 & 127,8 & 7,8 \\
Çıplak alanlar & 499,9 & 30,5 & 555,0 & 33,8 & 280,6 & 17,1 \\
Lagün/ Su kütlesi & 119,3 & 7,3 & 112,4 & 6,8 & 129,9 & 7,9 \\
\hline
\end{tabular}




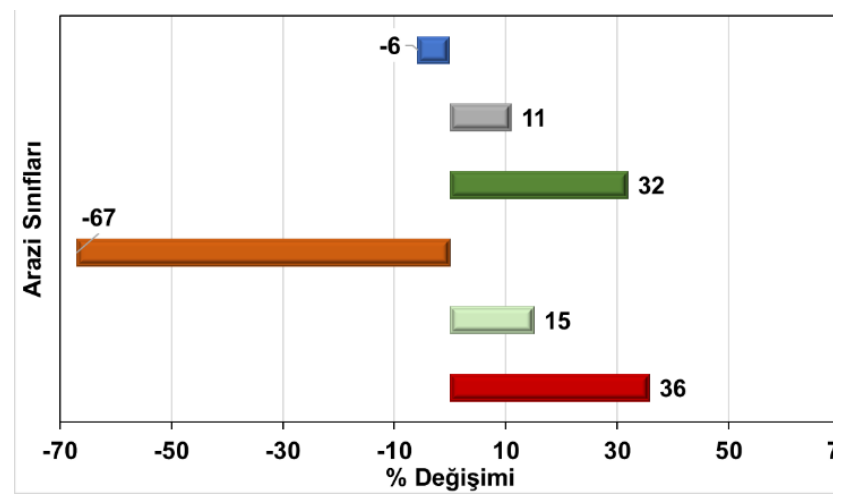

(a)

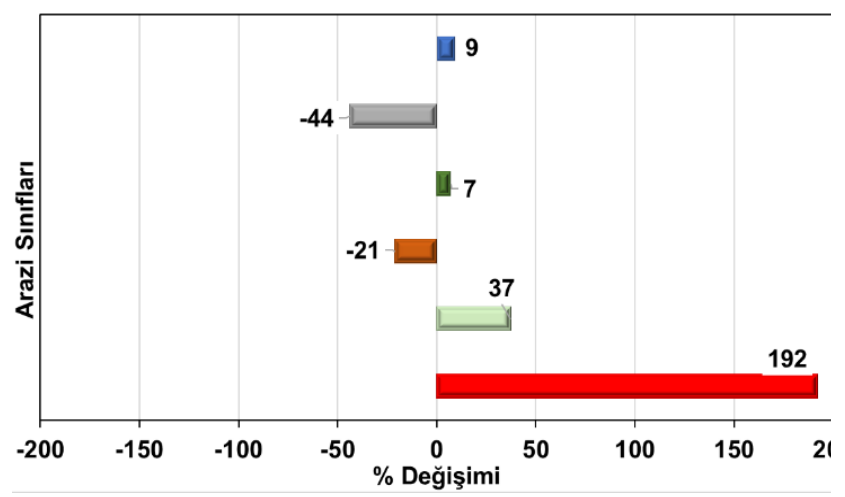

(c)

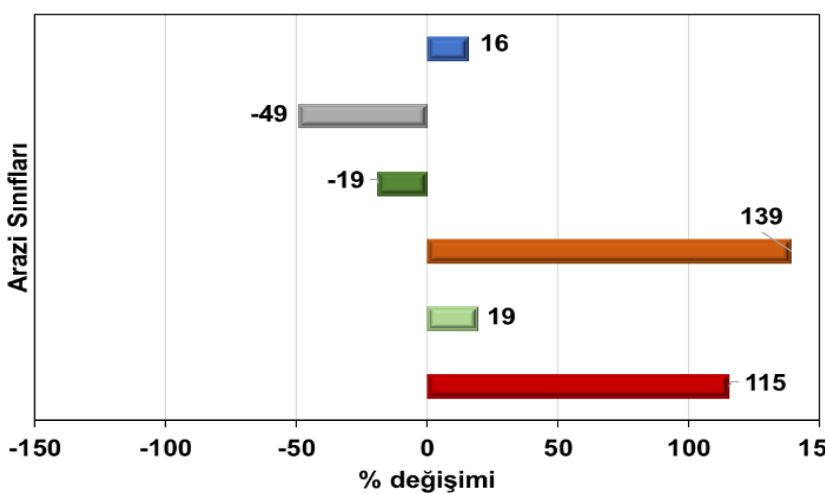

(b)

Şekil 11: a) 1985-2000, b) 2000-2019, c) 1985-2019 yılları arasında arazi sınıflarında meydana gelen değişim yüzdeleri

Tablo 2: Çalışma alanı arazi sınıflarında meydana gelen değişim (1985, 2000 ve 2019)

\begin{tabular}{lcccccc}
\hline & \multicolumn{2}{c}{$1985-2000$} & \multicolumn{2}{c}{$2000-2019$} & \multicolumn{2}{c}{$1985-2019$} \\
\hline \multicolumn{1}{c}{ Arazi Sınıfları } & $\begin{array}{c}\text { Alan } \\
\left(\mathrm{km}^{2}\right)\end{array}$ & $\begin{array}{c}\text { Değişim } \\
(\%)\end{array}$ & $\begin{array}{c}\text { Alan } \\
\left(\mathrm{km}^{2}\right)\end{array}$ & $\begin{array}{c}\text { Değişim } \\
(\%)\end{array}$ & $\begin{array}{c}\text { Alan } \\
\left(\mathrm{km}^{2}\right)\end{array}$ & $\begin{array}{c}\text { Değişim } \\
(\%)\end{array}$ \\
\hline Yerleşim alanlar & 15,3 & 35,8 & 20,8 & 115,3 & 44,7 & 192,3 \\
$\begin{array}{l}\text { Ekili olmayan tarım } \\
\text { alanlar }\end{array}$ & 613,8 & 15,0 & 706,1 & 19,4 & 843,3 & 37,4 \\
$\begin{array}{l}\text { Ekili tarım alanlar } \\
\text { Orman ve yarı doğal }\end{array}$ & 273,6 & $-67,0$ & 90,2 & 139,1 & 215,8 & $-21,2$ \\
alanlar & 119,4 & 31,9 & 157,5 & $-18,9$ & 127,8 & 7,0 \\
Çıplak alanlar & 499,9 & 11,0 & 555,0 & $-49,4$ & 280,6 & $-43,9$ \\
Lagün/ Su kütlesi & 119,3 & $-5,8$ & 112,4 & 15,5 & 129,9 & 8,8 \\
\hline
\end{tabular}

2014 yılında yürürlüğe giren “Mekansal Planlar Yapım Yönetmeliği, Çevre Düzeni Planlarına Dair Esaslar” bölümünde yerleşim yerlerinde yapılması gereken planlama çalışmalarında, afet tehlikelerine ilişkin risklerin ve bölgeye ait jeolojik yapının dikkate alınması ile afet risklerini azaltıcı önerilerin dikkate alınması maddesi yer almaktadır (URL-4 2014). Aynı zamanda yerleşim yerlerinin büyümesine yönelik yapılacak planlamalarda, mikro ve makro boyutlarda jeolojik, jeomorfolojik, hidrolojik, toprak, doğal afet olası tehlikeleri, yerleşime uygunluk, risk yönetimi ve sakınım planlarının da değerlendirilmesine yönelik kararlar bulunmaktadır. Bu kapsamda, çalışma alanı içerisinden geçmekte olan ve Türkiye diri fay haritasına göre (Emre vd. 2018) önemli aktif fay hatlarından biri olan ve son 100 yıllık süreçte birçok deprem oluşturan Karataş fayının (Şekil 12a) geçmesi sebebiyle, Karataş fayı boyunca 500, 1000 ve 2000 metrelik tampon bölgeler oluşturularak arazi sınıflamasında meydana gelen değişimler incelenmiştir.

1985, 2000 ve 2019 yıllarına ait arazi kullanım haritaları, belirlenen tampon bölge sınırlarına göre incelenmiş olup; 500, 1000, 2000 m'lik tampon bölge sınırlarında en yüksek yüzdeyi 1985 (Şekil 12b), 2000 (Şekil 12c), 2019 (Şekil 12c) yıllarında çıplak alanların oluşturduğu belirlenmiştir. 
Aktif fay hatları boyunca yerleşim birimlerinin artması gelişecek muhtemel bir deprem sonrasında insan yaşamı ve doğal yapılarda meydana gelecek kayıplar için risk oluşturmaktadır. Mekansal planlamalarda fay hatlarına uzak yerleşim alanlarının seçilmesi önemli bir kriter olmaktadır. Fakat çalışma alanında yapılan analizler sonucunda 1985, 2000 ve 2019 yıllarında yerleşim birimlerinin Karataş fayı boyunca büyüdüğ̈̈ görülmektedir. 500 m, 1000 ve 2000 m'lik tampon bölge sınırlarında sırasıyla \% 156, \% 238 ve \% 328 olan yerleşim bir artış olduğunu göstermektedir (Şekil 13).

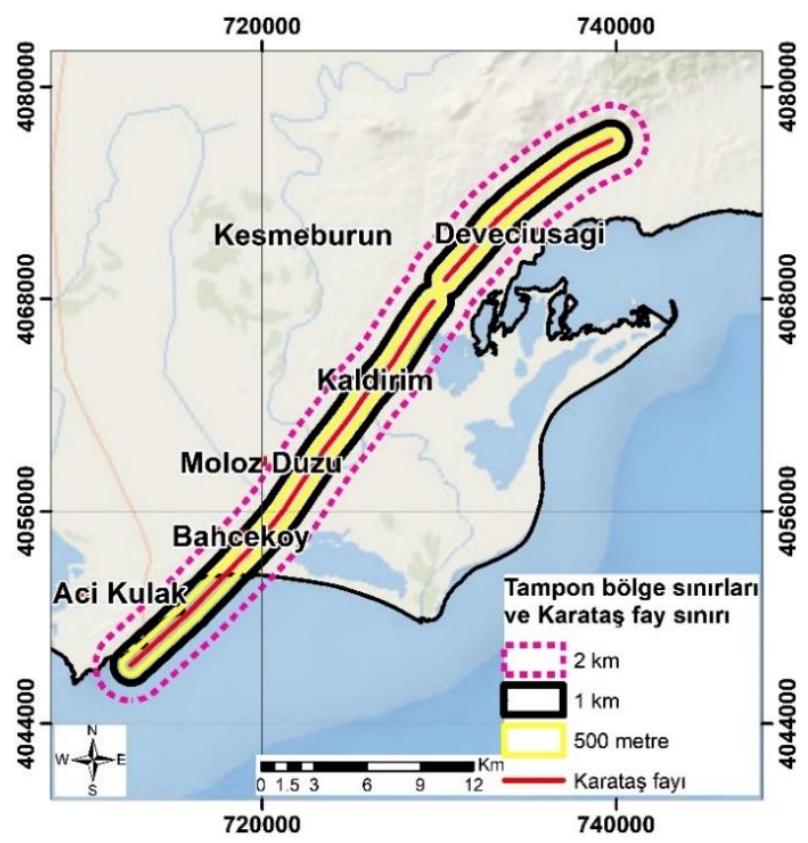

(a)

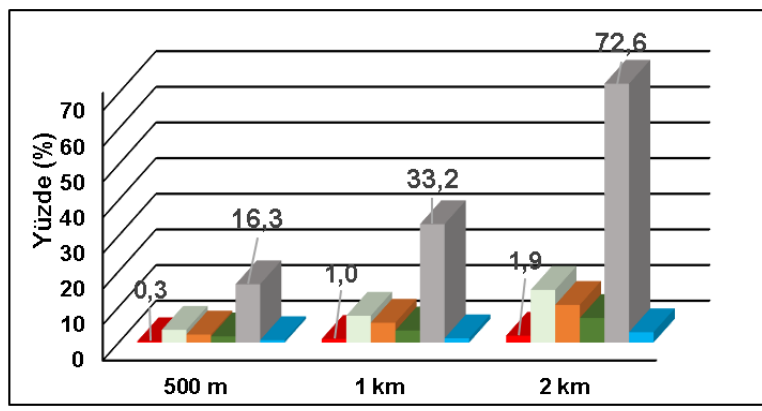

(b)

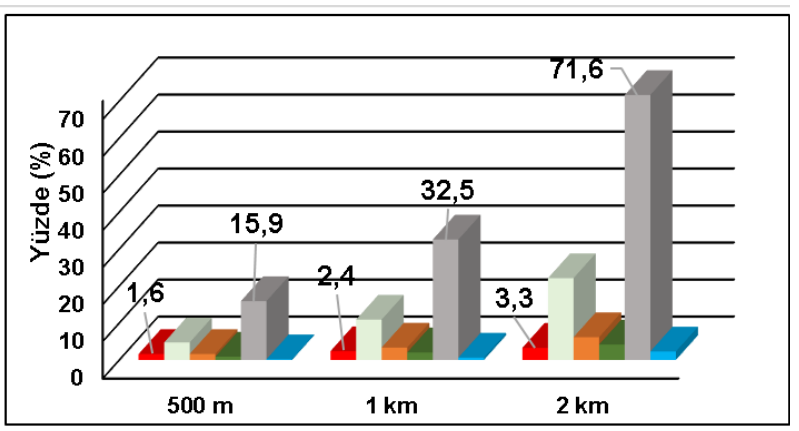

(c)

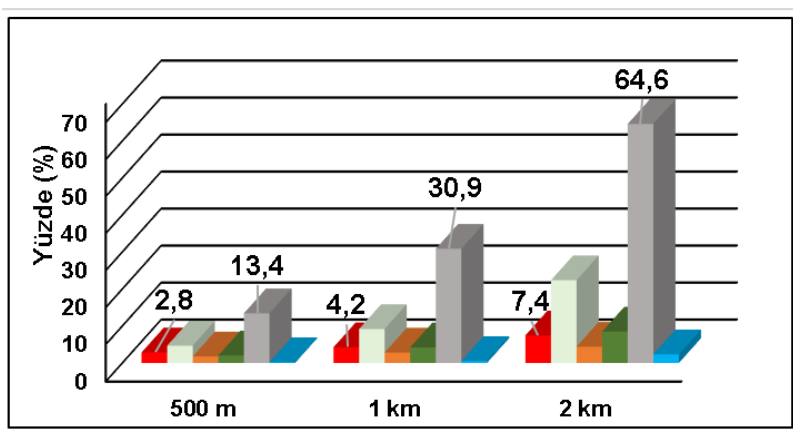

(d)

Şekil 12: a) Karataş fayı civarına ait 500, 1000 ve 2000 m'lik tampon bölgeler, b) 1985, c) 2000, d) 2019 yıllarına ait 500 , 1000 ve 2000 m'lik buffer zonlarındaki arazi sınıfları 


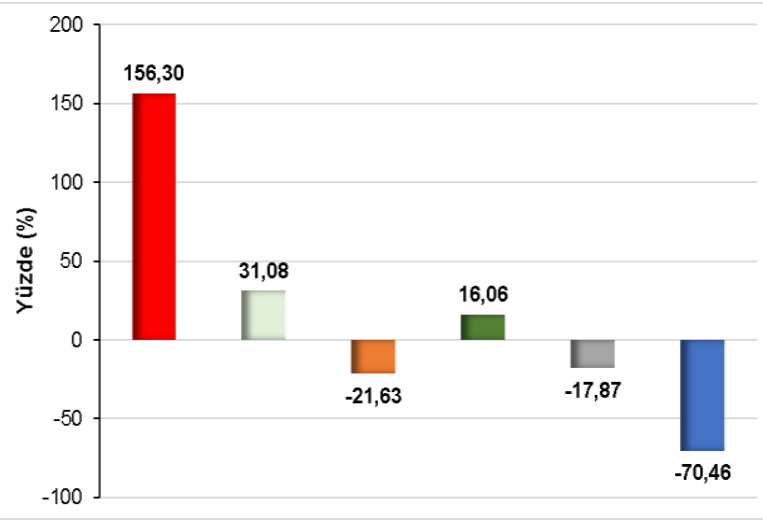

(a)

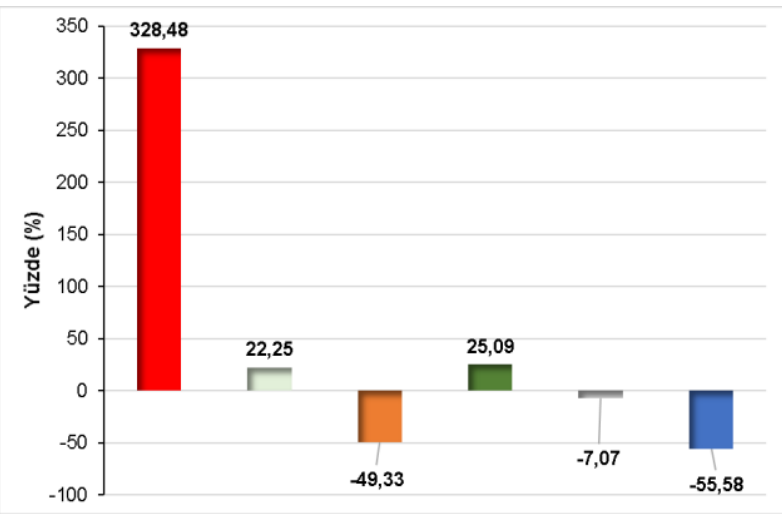

(c)

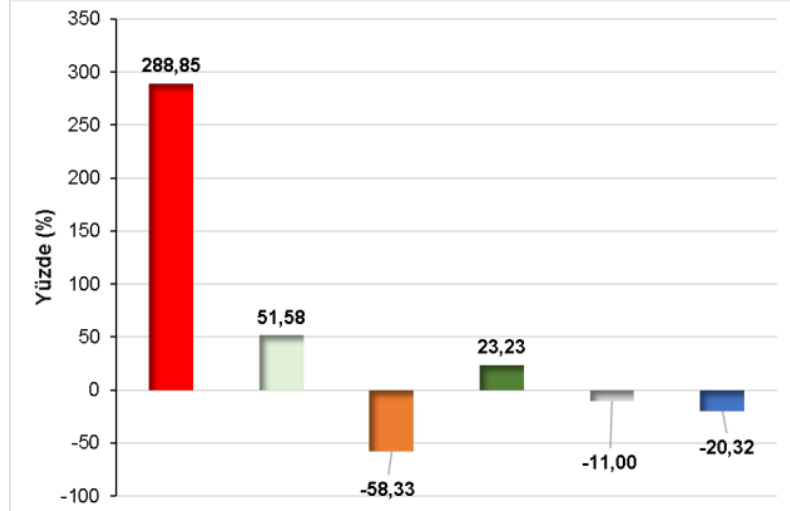

(b)

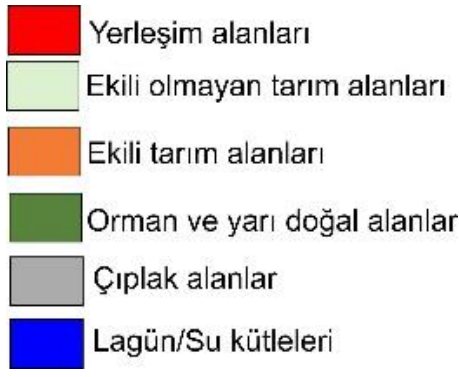

Şekil 13: 1985 - 2019 yılları arasında a) 500, b) 1000 ve c) 2000 m’lik tampon bölgelerde meydana gelen arazi sınıflarına ait değişim yüzdeleri

Sınıflamaların performans değerlendirmesi genel doğruluk için hata matrisi, sınıflamalar arasındaki istatistiksel farklılıklar ise Kappa istatistiği kullanılarak yapılmıştır. Kappa istatistiği, referans verileri ile kullanıcı tarafından tanımlanan sınıflama verileri arasındaki bir ölçüm mekanizmasıdır (Cohen 1960; Landis ve Koch 1977). Referans olarak toprak haritaları, topoğrafik haritalar, Google Earth görüntüleri, arazi gözlemlerinden edilen veriler kullanılmıştır. Arazi sınıflarına ait doğruluk istatistiksel yaklaşımlara dayanan kappa katsayısı ( $\kappa)$ ile hesaplanmıştır. Kappa istatistiği ile elde edilen Kappa katsayısı 0 - 1 arasında sonuç vermektedir. 1985, 2000 ve 2019 yıllarına ait belirlenen sınıfların doğruluk analizleri her üç zaman içinde 185 noktaya ait genel doğruluk ve Kappa değerleri hesaplanmıştır. Buna göre; Sınıflandırma hata matrisleri incelendiğinde, sınıfların toplam Kappa değerleri, 1985, 2000 ve 2019 yılları için sırasıyla 0.77, 0.82 ve 0.86 olarak hesaplanmıştır (Tablo 3).

Tablo 3: Kappa istatistiği ve genel doğruluk sonuçları

\begin{tabular}{|c|c|c|c|c|c|c|}
\hline & \multicolumn{2}{|c|}{1985} & \multicolumn{2}{|c|}{2000} & \multicolumn{2}{|c|}{2019} \\
\hline & $\begin{array}{c}\text { Referans } \\
\text { verileri }\end{array}$ & $\begin{array}{c}\text { Tanımlama } \\
\text { verileri }\end{array}$ & $\begin{array}{c}\text { Referans } \\
\text { verileri }\end{array}$ & $\begin{array}{c}\text { Tanımlama } \\
\text { verileri }\end{array}$ & $\begin{array}{c}\text { Referans } \\
\text { verileri }\end{array}$ & $\begin{array}{c}\text { Tanımlama } \\
\text { verileri }\end{array}$ \\
\hline Yerleşim alanlar & 76.92 & 76.92 & 90.91 & 76.92 & 78.57 & 84.62 \\
\hline $\begin{array}{l}\text { Ekili olmayan tarım } \\
\text { alanlar }\end{array}$ & 76.92 & 76.92 & 84.62 & 84.62 & 84.62 & 84.62 \\
\hline Ekili tarım alanlar & 83.33 & 76.92 & 78.57 & 84.62 & 100 & 92.31 \\
\hline $\begin{array}{l}\text { Orman ve yarı doğal } \\
\text { alanlar }\end{array}$ & 84.62 & 84.62 & 78.57 & 84.62 & 100 & 92.31 \\
\hline Çıplak alanlar & 75.00 & 92.31 & 91.67 & 84.62 & 100.00 & 100.00 \\
\hline Lagün/ Su kütlesi & 81.82 & 69.23 & 91.67 & 84.62 & 84.62 & 84.62 \\
\hline Genel doğruluk & $\% 80.00$ & & \multicolumn{2}{|c|}{$\% 84.62$} & \multicolumn{2}{|c|}{$\% 87.91$} \\
\hline Kappa & 0.77 & & \multicolumn{2}{|c|}{0.82} & \multicolumn{2}{|c|}{0.86} \\
\hline
\end{tabular}




\section{Sonuçlar}

Bu çalışmada, Çukurova'nın güney kesiminde ekolojik olarak öneme sahip olan doğal koruma alanlarından olan Akyatan yaban hayatı geliştirme sahası, Tuzla lagünleri gibi yaban hayatı geliştirme sahaları ve koruma alanları, Magarsus Antik

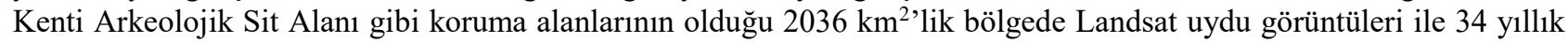
süre içerisinde arazi sınıflarında meydana gelen değişimler incelenmiştir. 32 km'si çalışma alanı içerisinde bulunan Karataş fayının 500, 1000 ve 2000 m'lik tampon bölge sınırları arasında kalan alanlarda yerleşimde meydana gelen artış hesaplatılmıştır. Yapılan sınıflamalarda 1985, 2000 ve 2019 yıllarında sırasıyla, yerleşim birimleri \%0.9, \%1.3, \%2.7, çıplak alanlar \% 0.5, \%33.8, \%17,1 orman ve yarı doğal alanlar \%7.3, \%9.6, \%7.8, Lagün/su kütlesi \% 7.3, \%6.8, \%7.9, ekili olmayan tarım alanlar \%37.4, \%43, \%51.4, ekili tarım alanlar \%16.7, \%5.5, \%13.1 olarak belirlenmiştir. Elde edilen sonuçlara göre; 1985 ve 2000 arazi değişim sınıflarından, ekili tarım (\%67) ve lagün/göller (\%5,8) alanlarda azalma meydana gelirken, yerleşim $(\% 35,8)$, ekili olmayan tarım $(\% 15)$, orman ve yarı doğal $(\% 31,9)$ ve çıplak $(\% 11)$ alanlarında artış meydana geldiği belirlenmiştir. 2000 ve 2019 için arazi değişim sınıflarından, çıplak $(\% 49,4)$ ve orman ve yarı doğal $(\% 18,9)$ alanlarda azalma meydana gelirken, yerleşim $(\% 115,3)$, ekili olmayan tarım $(\% 19,4)$, ekili tarım $(\% 139,1)$ ve lagün/ göller $(15,5)$ alanlarında artış meydana geldiği belirlenmiştir. 2000 ve 2019 için arazi değişim sınıflarından, çıplak $(\% 43,9)$ ve ekili tarım alanlarda $(\% 21,2)$ azalma meydana gelirken, yerleşim $(\% 192,3)$, ekili olmayan tarım $(\% 37,4)$, orman ve yarı doğal $(\% 7)$ ve lagün/ göller $(\% 8,8)$ alanlarında artış meydana geldiği belirlenmiştir. Bununla birlikte 19852019 tarihleri arasında çalışma alanında yer alan diri faylara 500, 1000 ve 2000 m'lik tampon bölge sırasıyla \% 156, \% 238 ve \% 328 olan yerleşim bir artış olduğunu göstermektedir.

\section{Kaynaklar}

Adep R.N., Shetty A., Ramesh H., (2017), EXhype: A tool for mineral classification using hyperspectral data, ISPRS Journal of Photogrammetry and Remote Sensing, 124, 106-118.

Agapiou A., Alexakis D.D., Sarris A., Themistocleous K., Papoutsa C., Hadjimitsis D.G., (2014), Satellite-derived land use changes along the Xin'an river watershed for supporting water quality investigation for potential fishing grounds in Qiandao Lake, China Second International Conference on Remote Sensing and Geoinformation of the Environment (Rscy2014) Volume 9229 içinde, (Hadjimitsis D.F., Themistocleous K., Michaelides S., Papadavid G., Ed.), doi: 10.1117/12.2066314.

Ahmad N., Ahsan N., Said S., (2019), Land use mapping of Yamuna river flood plain in Delhi using K-Mean and spectral angle image classification algorithms, Water and Energy International, 62(5), 63-68.

Anggraeni A., Lin C.S., (2011), Application of SAM and SVM Techniques to Burned Area Detection for Landsat TM Images in Forests of South Sumatra, 2nd International Conference on Environmental Science and Technology, volüme 6 içinde, Singapore, ss.160164.

Aswatha S.M., Mukhopadhyay J., Biswas P.K., (2017), Semi-supervised classification of land cover in multi-spectral images using spectral slopes, Proceedings Ninth International Conference on Advances in Pattern Recognition (Icapr) içinde, Bangalore, India, ss.338-343.

Awad M.M., (2018), Forest mapping: a comparison between hyperspectral and multispectral images and technologies, Journal of Forestry Research, 29, 1395-1405.

Borges E.F., Sano E.E., (2014), Temporal series of EVI from MODIS sensor for land use and land cover mapping of western Bahia, BCG - Boletim de Ciências Geodésicas, doi:10.1590/S1982-21702014000200030.

Carvalho L.M.T., Fonseca L.M.G., Murtagh F., Cleves J.G.P.W., (2001), Digital change detection with the aid of multiresolution wavelet analysis. International Journal of Remote Sensing, 22, 3871-3876.

Cohen J.A., (1960), Coefficient of agreement for nominal scales, Educational and Psychological Measurement, 20, 37-46.

Dennison P.E., Halligan K.Q., Roberts D.A., (2004), A comparison of error metrics and constraints for multiple endmember spectral mixture analysis and spectral angle mapper, Remote Sensing of Environment, 93(3), 359-367.

Elatawneh A., Manakos I., Kalaitzidis C., Schneider T., (2010), Land-cover classification and unmixing of hyperion image in area of Anopoli, Imagin [E,G] Europe, Proceedings of the 29th Symposium of the European Association of Remote Sensing Laboratories içinde, (Manakos I, Kalaitzidis C., Ed.), Greece, ss. 111-121.

Elmahdy S.I., Mohamed M.M., (2016), Land use/land cover change impact on groundwater quantity and quality: a case study of Ajman Emirate, the United Arab Emirates, using remote sensing and GIS, Arabian Journal of Geoscience, doi: 10.1007/s12517016-2725-y.

Emre Ö., Duman T.Y., Özalp S., Şaroğlu F., Olgun Ş., Elmacı H., Çan T., (2018), Active fault database of Turkey, Bulletin of Earthquake Engineering, 16(8), 3229-3275.

Fan C., Zhang P., Wang S., Hu B., (2018), A study on classification of mineral pigments based on spectral angle mapper and decision tree, Tenth International Conference on Digital Image Processing (ICDIP 2018) Proceedings Volume 10806 içinde, Shanghai, China, doi:10.1117/12.2503088.

Fick, S.E. and R.J. Hijmans, 2017. Worldclim 2: New 1-km spatial resolution climate surfaces for global land areas. International Journal of Climatology.

Forzieri G., Tanteri L., Moser G., Catani F., (2013), Mapping natural and urban environments using airborne multi-sensor ADS40MIVIS-LiDAR synergies, International Journal of Applied Earth Observation and Geoinformation, 23:313-323.

Gannouni S., Rebai N., (2020), Comparative Analysis of the Classification of Maximum Reality (MVS) and the Spectral Angle Mapper (SAM) of an Aster Image. Case Study: Soil Occupancy in the Main Area (Tunisia), In Mapping and Spatial Analysis of Socioeconomic and Environmental Indicators for Sustainable Development, Springer, Cham, doi:10.1007/978-3-030-21166-0_5. 
Gopinath G., Sasidharan N., Surendran U., (2020), Landuse classification of hyperspectral data by spectral angle mapper and support vector machine in humid tropical region of India, Earth Science Informatics, doi:10.1007/s12145-019-00438-4 1-8.

Gündoğan A.C., Aydın C.İ., Voyvoda E., Turhan E., Özen İ.C., (2017), İklim değişikliği hedeflerine ulaşılamamasının Türkiye’ye maliyeti üzerine ortak sosyoekonomik patikalar perspektifinden bir değerlendirme, WWF-Türkiye, (Berke M.Ö. Ed.), Yeryüzü Derneği Yayınları - 7, 84 ss.

Gürsoy, Ö., (2016). Determining the most appropriate classification methods for water quality. In IOP Conference Series: Earth and Environmental Science, IOP Publishing, Vol. 44, No. 2, p. 022038.

Helmer E.H., Brown S., Cohen W.B., (2000), Mapping montane tropical forest successional stage and land use with multi-date Landsat imagery, International Journal of Remote Sensing, 21(11), 2163-2183.

Huang B., Zhang H.K., Yu L., (2012), Improving Landsat ETM plus urban area mapping via spatial and angular fusion with MISR multi-angle observations, IEEE J. Sel. Top. Appl. Earth Observ. Remote Sensing, 5(1), 101-109.

Irish R.R., Barker J.L., Goward S.N., Arvidson T., (2006), Characterization of the Landsat-7 ETM+ automated cloud-cover assessment (ACCA) algorithm, Photogrammetric Engineering \& Remote Sensing, 72(10), 1179-1188.

Islam K., Jashimuddin M., Nath B., Nath T. K., (2017), Land use classification and change detection by using multi-temporal remotely sensed imagery: The case of Chunati wildlife sanctuary, Bangladesh, The Egyptian Journal of Remote Sensing and Space Sciences, 21(1), 37-47.

Karabulut A., Elbaşı F., Ustaoğlu S., Yatman D., (2011), Türkiye büyük toprak grubu haritası, Tarımsal Araştırmalar ve Politikalar Genel Müdürlüğü Toprak Gübre ve Su Kaynakları Merkez Araştırma Enstitüsü Müdürlüğü, Mekanizasyon ve Bilişim Teknolojileri Bölümü, Ankara.

Karakus P., Karabork H., Kaya S., (2017), A comparison of the classification accuracies in determining the land cover of Kadirli Region of Turkey by using the pixel based and object based classification algorithms, International Journal of Engineering and Geosciences (IJEG), 2(2), 52-60.

Kruse F.A., Lefkoff A.B., Boardman J.B., Heidebrecht K.B., Shapiro A.T., Barloon P.J., Goetz A.F.H., (1993), The spectral image processing system (SIPS) - interactive visualization and analysis of imaging spectrometer data, Remote Sensing of Environment 44(2-3), 145-163.

Landis J.R., Koch G.G., (1977), The measurement of observer agreement for categorical data, Biometrics, 33(1), 159-174.

Luc B., Deronde B., Kempeneers P., Debruyn W., Provoost S., (2005), Optimized spectral angle mapper classification of spatially heterogeneous dynamic dune vegetation, a case study along the Belgian coastline, 9th International Symposium on Physical Measurements and Signatures in Remote Sensing (ISPMSRS), Beijing, China.

Lunetta R. S., and Elvidge C.D., (1998), Remote Sensing change détection, environmental monitoring methods and applications. Ann Arbor Press,Ann Arbor(Michigan) 318 p.

Massironi M., Bertoldi L., Calafa P., Visonà D., Bistacchi A., Giardino C., Schiavo A., (2008), Interpretation and processing of ASTER data for geological mapping and granitoids detection in the Saghro massif (eastern AntiAtlas, Morocco). Geosphere, 4, 736-759.

Nigussie T.A., Altunkaynak A., (2019), Modeling the effect of urbanization on flood risk in Ayamama Watershed, Istanbul, Turkey, using the MIKE 21 FM model, Natural Hazards, 99, 1031-1047.

Olayiwola A.M., Fakayode O., (2019), Landscape metrics analysis of land use patterns and changes in suburban local government areas of Ibadan, Nigeria, South African Journal of Geomatics, 8(2), 209-220.

Padmanaban R., Bhowmik A.K., Cabral P., (2019), Satellite image fusion to detect changing surface permeability and emerging urban heat islands in a fast-growing city, Plos One, doi: 10.1371/journal.pone.0208949.

Paul B.K., Rashid H., (2017), Land use change and coastal management, Climatic Hazards in Coastal Bangladesh, Non-Structural and Structural Solutions içinde, ss. 183-207, https://doi.org/10.1016/B978-0-12-805276-1.00006-5.

Putro S.T., Prasetiyowati S.H., (2019), Challenges in collecting primary data for environmental research purposes: a case study in Parangtritis sand dune, Yogyakarta, First International Conference on Environmental Geography and Geography Education (Icege) 243, doi:10.1088/1755-1315/243/1/012004.

Rahman M.K., Schmidlin T.W., Munro-Stasiuk M.J., Curtis A., (2019), Geospatial analysis of land loss, land cover change, and landuse patterns of Kutubdia Island, Bangladesh, Environmental Information Systems: Concepts, Methodologies, Tools, and Applications içinde, doi:10.4018/978-1-5225-7033-2.ch048.

Rowan, L. C., Mars, J. C., \& Simpson, C. J., (2005). Lithologic mapping of the Mordor, NT, Australia ultramafic complex by using the Advanced Spaceborne Thermal Emission and Reflection Radiometer (ASTER). Remote sensing of Environment, 99 (1-2), 105-126.

Stow D.A., (1999), Reducing the effects of misregistration on pixel-level change detection, International Journal of Remote Sensing, 20, 2477-2483.

Thanikachalam M., Nimalan K., (2019), Investigation and prediction of urban-sprawl and land-use changes for Chennai city using geo-spatial technologies, Indian Journal of Geo-Marine Sciences (IJMS), 48(09), 1443-1451.

Tornaghi C., Dehaene M., (2019), The prefigurative power of urban political agroecology: rethinking the urbanisms of agroecological transitions for food system transformation, Agroecology and Sustainable Food Systems, doi:10.1080/21683565.2019.1680593.

Ulu Ü., (2009a). 1/100000 Ölçekli Türkiye Jeoloji Haritaları Mersin-O33 Paftası, Maden Tetkik ve Arama Jeoloji Etütleri Dairesi, Ankara.

Ulu Ü., (2009b). 1/100000 Ölçekli Türkiye Jeoloji Haritaları Mersin-O34 Paftası, Maden Tetkik ve Arama Jeoloji Etütleri Dairesi, Ankara

URL-1, (2019), CORINE, (Coordination of Information on the Environment), (2018), CORINE Land Cover, https://land.copernicus.eu/pan-european/corine-land-cover, [Erişim 14 Aralık 2019]

URL-2, (2019), CORINE (Çevresel Bilginin Koordinasyonu), https://corinecbs.tarimorman.gov.tr/corine, [Erişim 14 Aralık 2019].

URL-3, (2020), WorldClim Maps, graphs, tables, and data of the global climate, http://www.worldclim.org/version1, [Erişim 15 Mart 2020].

URL-4, (2014), Mekânsal Planlar Yapım Yönetmeliği, Resmî Gazete Tarihi: 14.06.2014 Resmî Gazete Sayısı: 29030, https://www.mevzuat.gov.tr/Metin.Aspx?MevzuatKod=7.5.19788\&Mevzuatlliski=0\&sourceXmlSearcmekan, [Erişim 30 Mart 2020]. 
Uysal M, Turgut B, Polat N, Mehmet A. D, Yalçın M., (2017), Uzaktan algılama teknikleri ile açık maden ocaklarında bor minerallerinin tespiti, Afyon Kocatepe Üniversitesi Fen ve Mühendislik Bilimleri Dergisi, 17, Özel Sayı, 270-276.

Verbyla D.L., Boles S.H., (2000), Bias in land cover change estimates due to misregistration, International Journal of Remote Sensing, $21,3553-3560$

Wiafe E.D, Asamoah G., (2018), Land-cover change assessment in Ejisu -Juabeng district in Ghana, Eurasian Journal of Forest Science, 6(1), 1-8.

Yoon E., Thorne J., Park C., Lee D.K., Kim K., Yoon H., Seo C., Lim C.H., Kim H., Song Y., (2019), Modeling spatial climate change landuse adaptation with multi-objective genetic algorithms to improve resilience for rice yield and species richness and to mitigate disaster risk, Environmental Research Letter, 14(2), 1-10. 